む、るし者に落

、自村てとかは戦

そ小落抬しなっ時

の作支頭て り地卡

組、・配層す盗確主

み小層す資確的

入、作のる格に秩部

方層かな方条斦な落

にのに、つ穴い齐

関支組自耕 2 ᄂ 配

乙配 み自作し、地造

は會れ作主古所は

更組れ方去地㤫よ

更組れ作寄地者之

に棸㤰告有秩炎

検入会盧地㤫序瓷

討れて曾主者心よ

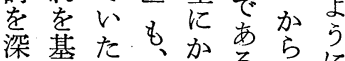

染基た。、加るらに

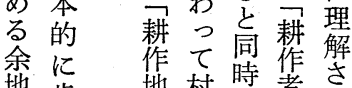

地肯 地村に者さ

残定圭敋小仲て

さし 中支商間い

れな゙核配品的る。

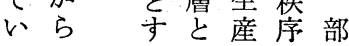

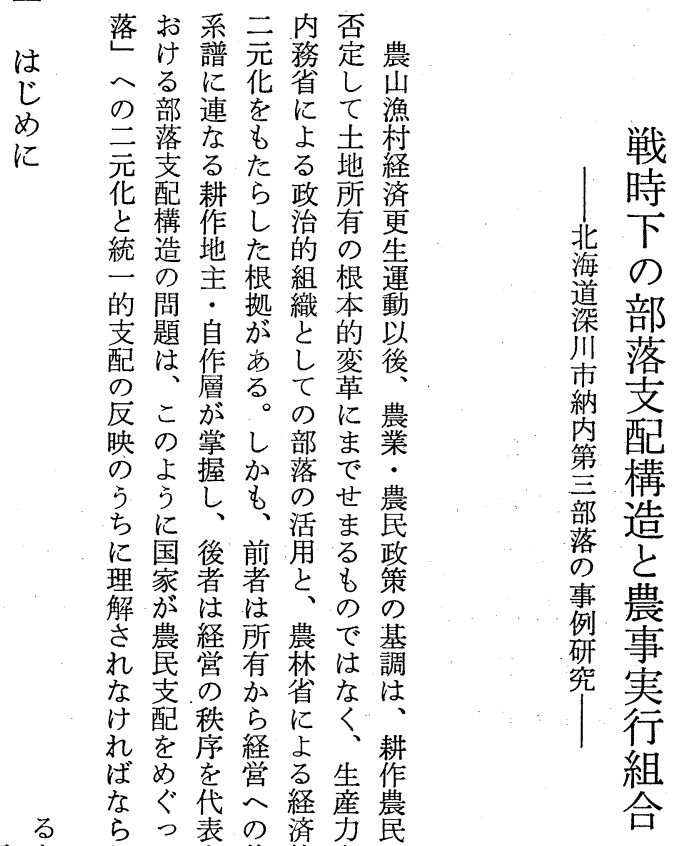

し農ずて経農農織

らっ表の済力民

、山、怪済事民へ元と、なて基的主の 積漁部、済害的政来思 以示る調組義保 極村落農へ行小治わ的自変織的護

的経は事令組商的部れ

に済制実の合品部落る

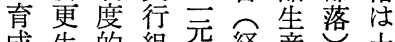

成生的組元経産志

活運に合慟済ので地

た作を华と变直

政: 含て内接

紫小みので的

治作な部行掌

と層らが落わ握

用のつ文部展っ有

し歴政経る。落老た者

た史治済

こ的的的但 が景こ権

と意部部し、形京の利

に義落落農成に部主

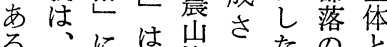

る、には山さ渔れたのと

。部二任漁れたた方

戦落元意村て農だる

時の化の経ゆ事な国

下三さ电済く改か家

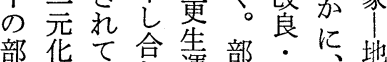

落をいわ運落流主

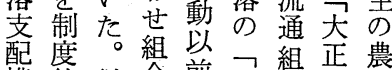

䣿的従合前政織期唇

造にっにに治織忿支

は公てすすあ認、苔降配

経笔農たと、

済掌概実れ明

の守し行で確

ズるて組あな

レと所合っ転

方のの妾佐

政関秩育こ示

治係序成こし

的㤎"

部 み伝 活国

落 ら統用家但

机的女。L

とた名い農

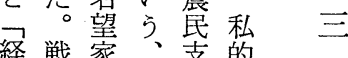

済時支部配所

的下配落が有

部にのの、を 
といと的か、題て、のぜつ配かがいりの上とら、゙こ

りたす組け北で、統かまし。、大て込排層して政なな

あとれ織て北あ戦二。たたそ戦正いん除はて政から三

げ推ば化の海る時体戦こ自の時後るでさつ考治しなつ

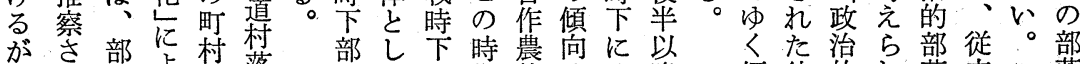

がさ部に村禁部し下時農向に以

落っ立洛落ての期的は入降

そる。て産多齐理部落部部る落政

れ。三て組多配解落農落落占政

先こ元よ部は造、実とに時的

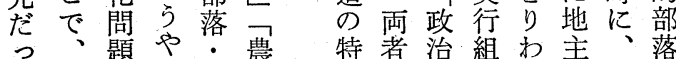

て北はく実山質の的合けを逆落

海北部行漁

戦道海落組村

時深道の合 経

を階部の顕欠にに

明級落国著きそ進

万的家㴧こ出

下川の確と済

、市諸立心更

か と的み作か儿

に機子育ら層らつ

政蒳部をう生

寸能経成れが排つ

治第に洛みル連

る的済・る部除あ

傾彼的れ落来、落

向 $ら$ 部て役、の

がが落き員自一階

顕马役た炒級

著経員こ作的

な済か文長小機

る部らま組作能

が落排た組虔的

こ賲さし除む評の分

兄杂方評支索統

点農ゆ戦謮配層

こ関的活 が落さっ

と係部用、へれた

部部よ文期

落落顕指よら

かを著摘る戦

、落とそ政て自

そ問元れ治ゆ小

れうの致は的く作

作役っ自合杂解

関事く下重への

尔奉傾に重 の ら

る検組にる向等組号に

事にさ農時

ら例現礼家体

のとわるの制

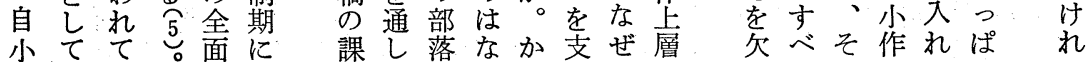

本とるる ぜ落の小

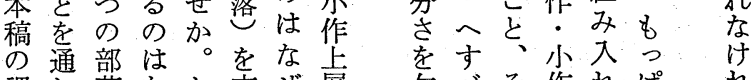

十員た小組は、さ

Z 落なコ期っ昭重十和後で層っ一家てし中

の採㤎養間た和立一恐退が清た表"い、に秋

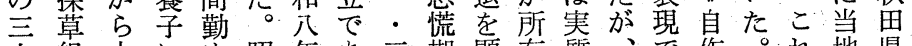

分組大にめ昭年あ三期顕有翼昭む゙作これ地県

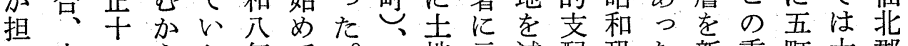

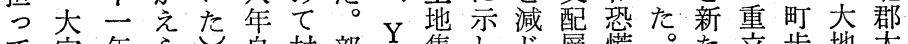

て字年ら自村部 $\mathrm{Y}$ 集しし層慌。た立歩地太

ゆ太にれ $Z$ 小会落五積たるの施にに支の主田

く田重た $Z$ 作議吾町を。加発の加配小に町

。部立母覔員第町進彼、位生時えは耕属

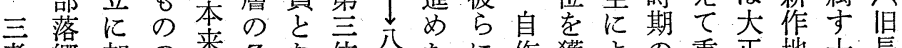

者郥加の来 Z 位分たに作獲よの重正地士長

は倉え中家加り立町 $\mathrm{X}$ 地得っ自立末主五信

昭委方途家部、地、へおをして作者以を? 田

和竟れ分本落士主 $Z$ 㚐っ天て重層を降加三村

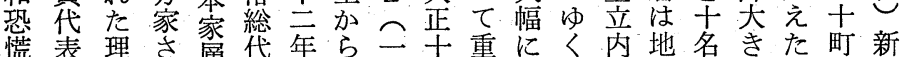

慌表理さ層代年ら一主重にく、内地名き縮。部主にく吾步

前どだた自なは躍三年層小四の層倍変至余部

隻部と。作つ第筆町十の势勢増华がの落

的落いそ作た頭 $\downarrow$ 六中るの力藩しす重耕注

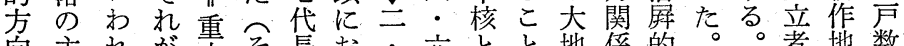

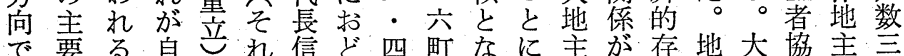

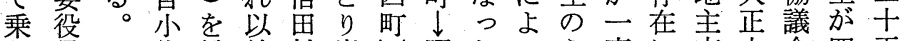

り員そ作継前村出昭たうう変に支十会四五

切はの層ぐは村たの和のてちし主配一弆戸户

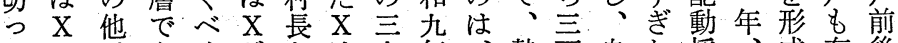

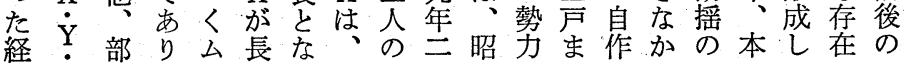

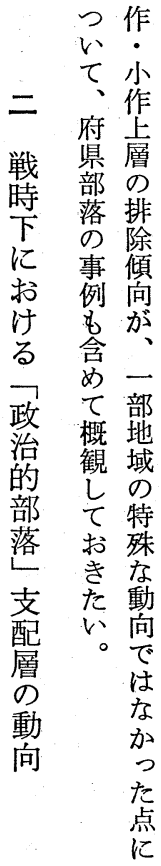


モ品さ長ったて接た三衤備系戦に通っ所は $\mathrm{Y}$ 時で営

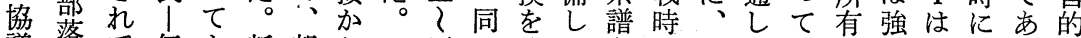

議洛て伍よ新部か三五じはたを下昭て氙を長はり夹

員䠂い長い田落わ○町くつ耕不新和い国経々信小煙力

会胥た。部はる町歩旧き作変田五た策営も思学草者

うを協小落おこ歩前長り地と部年。尔を村校栽層

協定新議神を去と余後信と主し落自こ遂兼え最淮培で

賛め田員成地そはの部定見層なに作の行備る初教もあ

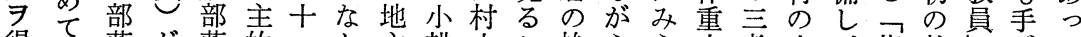

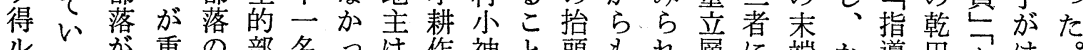

ルる便重の部名っは作神と頭もれ層に端か導田をけ

二。重立場落のた郡地成㤎にそる名加的つ、成勤るさ

アコ立で合と小。会主部で加のつ始え担、統功め耕ら

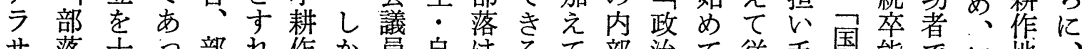

サ落十っ部れ作加貝息はるて部治て従手家能で経地

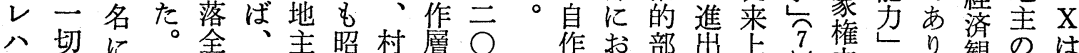

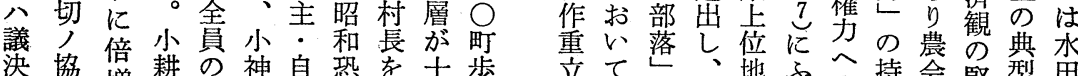

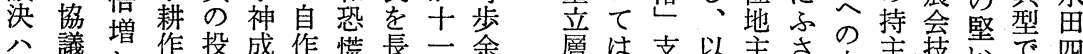

公議增作投成作慌長二余層は支以主さ主技等で四

確事し地票部層後期戸の の、配後五わ息で術しあ町

定項た時主で落のに隹々地発経層そ家し發あ員人っ歩

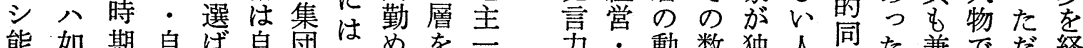

能如期息ば夏団没め、学文動数独人同た兼でだ経

八何小作九所向を占物調。水子け営

サナ小層た農支落部くを増有は堌しで有即るあで文

ルル神が区的配す落し別大: 、してあ有ち篤っなる

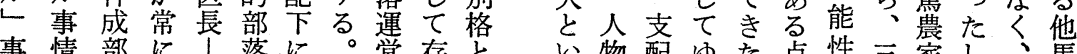

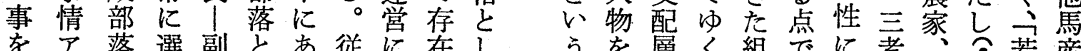

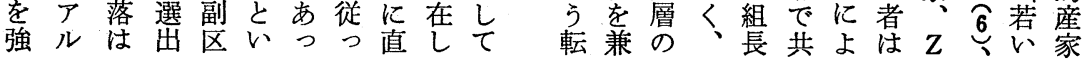

理作昭的区所にたに的小三の名十副う和にりでか調

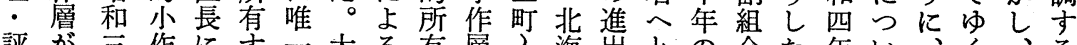

評が三作にす二大る有層々海出との合た年いくく、る

議一个農就る残正部階が五道は漸自長動をて昭。大そ

員挙七任部っ初落層言町深頭減小驾向除も和大正れ

にに年 C し 落た頭運構户歩川打し作小も、分来は

自焦のはた最出営成前所市とた上耕日て大年士か

小出間五の有田らでを後有納な。㽫作中正正に三ら小

作し区町は力兵昭あ常、の内り戦四地戦・正は年昭耕

: た長歩 B 者で和っと無自第、時名主争副年十始和作

小こををとであ三たし所作言逆下を!を組副名め初地

作と勤経 C あり年点て有層部にに追機合組のて頭主

層にめ営でる、までいのが落旧入、作に長合う自にに

がなてすあ。弟で、た約つ支るク層変の長ち小か自

名るいるっ $\mathrm{A}$ 三 $\mathrm{A}$ 小。作半詳配とにの調叒を四作け作

を。る尔た驾人が神部層数細層同、手势方名上て層

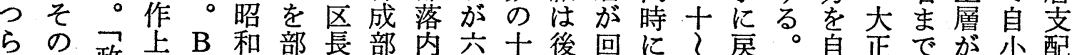

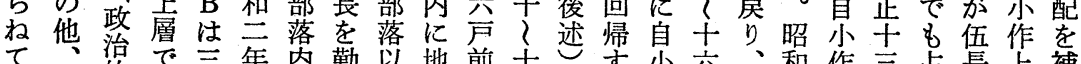

て昭的で三年内勤以地前十心玄六、和作豆点長上補

、昭部あ三転にめ上主後二はる作年伍十上年めに廜強

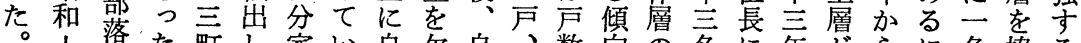

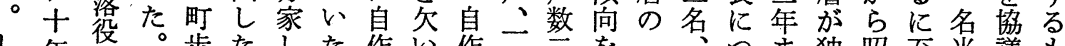

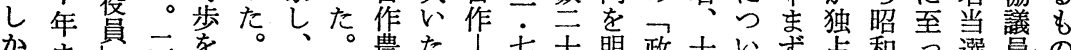

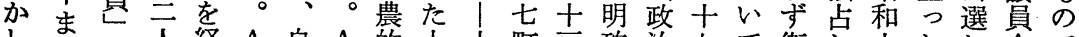

しでの全経 $\mathrm{A}$ 自 $\mathrm{A}$ 的上小町户確治七て衛し士たし会で

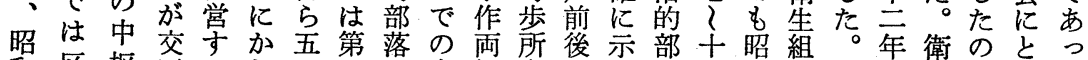

和区枢直るお町言で息極有三落九和合だに生をりた

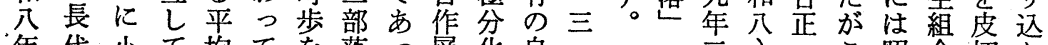

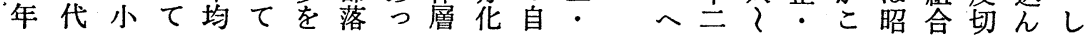




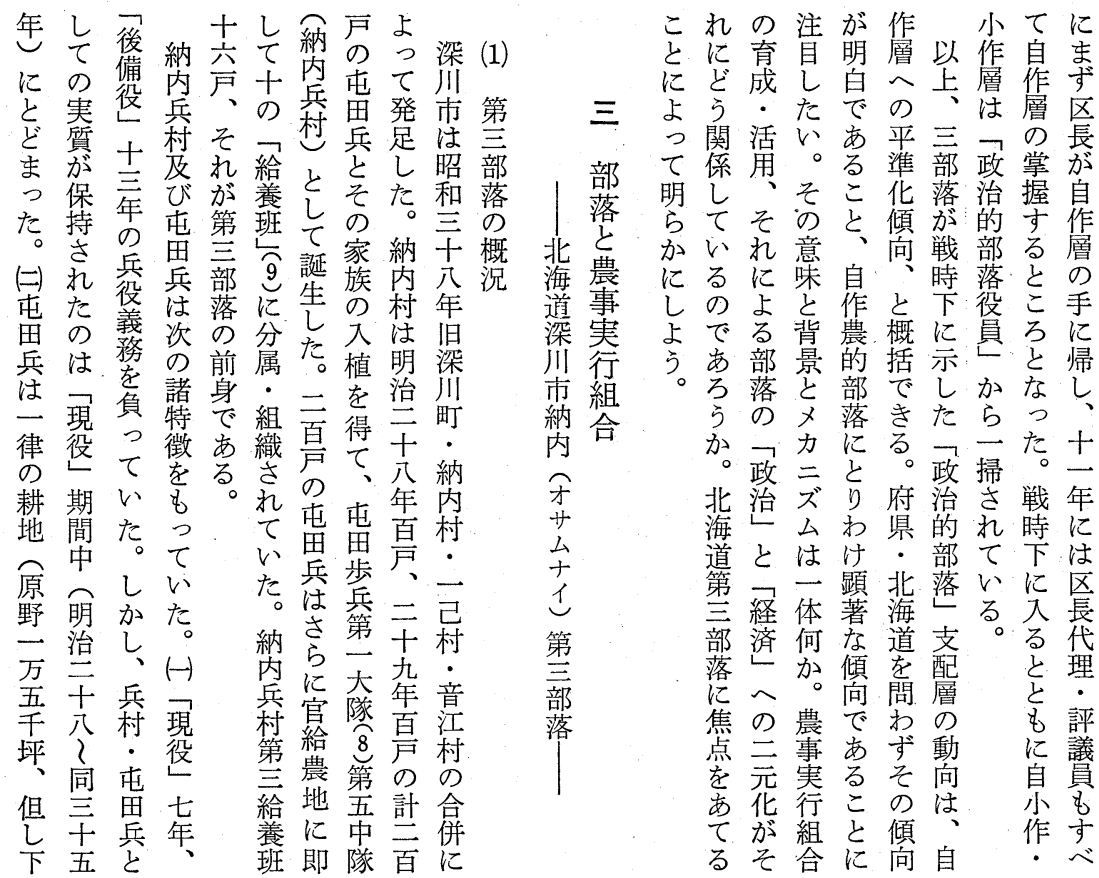

治昭 消地的兵果兵九わが軍除のっさ吕たの天朚あ士

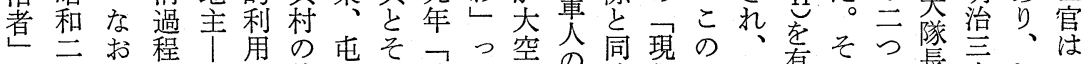

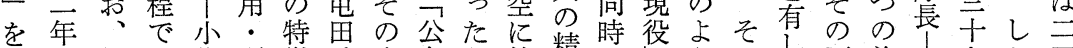

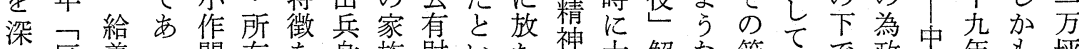
川区養っ関有を身族財いた神大解な管いで政隊年も坪 村に班た係の残分は産うれに隊除特理た者著解二し 盟改明 治称治。人性の在村委さょし隊に性と織㑟諮を用さ間

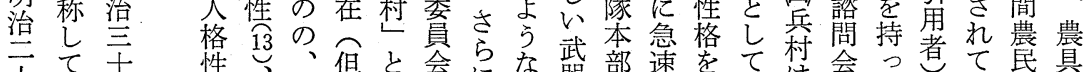

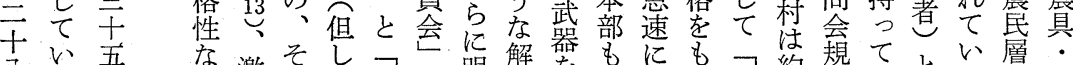

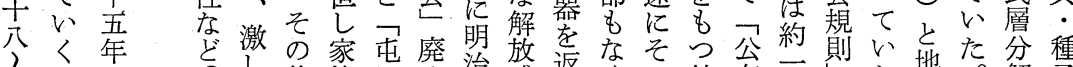

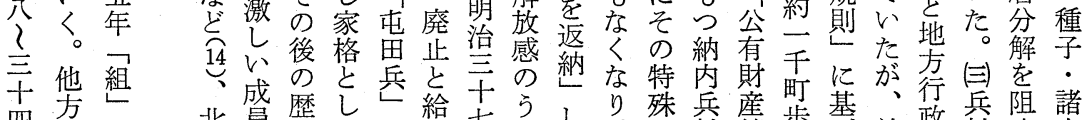

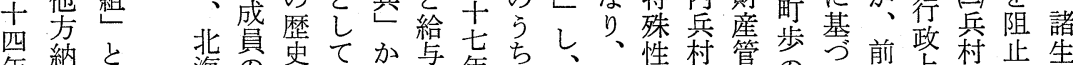

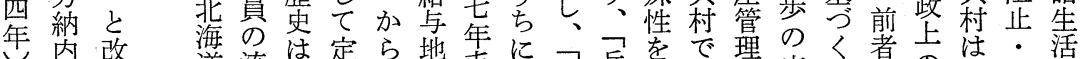

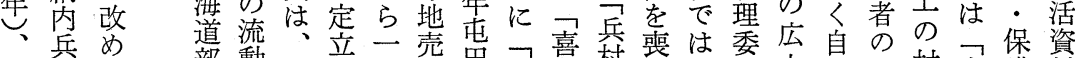

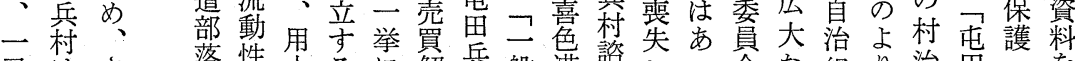
己はさ落性水るに解兵般満閭しつ会な組り治田つを

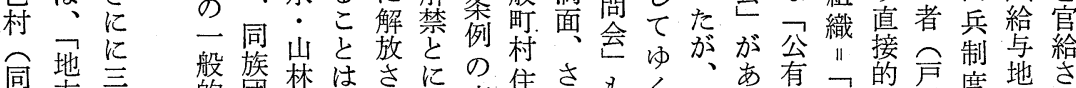

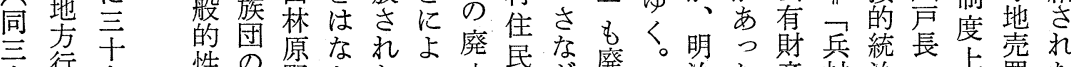

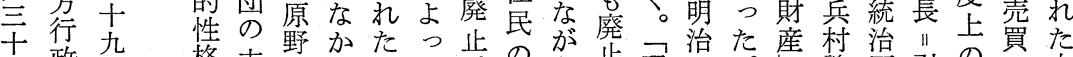

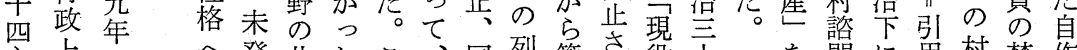

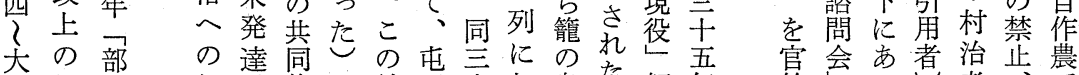

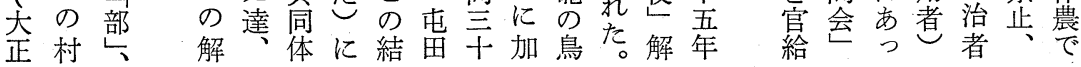


表 1 納内市街地で商業を始めた屯田兵

\begin{tabular}{|c|c|c|}
\hline 氏 名 & 開 業 年 & 備 \\
\hline Y.A.家 & 明治35年 & 荒物・雑貨商 \\
\hline M.K. & $\|$ & 運送業, 踹鉄 - 呉服商 \\
\hline S.S. & II & 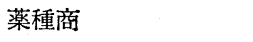 \\
\hline S.H. & "I & 馬具商 \\
\hline I. S. & 明治39年頃 & 料理店, 薬店 \\
\hline U.Y. & 明治40 $\|$ & 木材業 \\
\hline O.M. & $" \prime$ & 金物店（第 3 給養班） \\
\hline I. T. & $\|$ & 雑貨商（" ） \\
\hline $\mathrm{K} . \mathrm{B}$. & 明治42年以降 & 荒物・雑貨商 \\
\hline T. T. & $" \prime$ & 吳服商（第 3 給盖班） \\
\hline S.T. & "l & 食料・雑貨商 \\
\hline T.J. & "I & 浴 場 \\
\hline T.R. & II & 大 I \\
\hline H.S. & $\prime \prime$ & 畳 屋 \\
\hline 計 & 14 戸 & \\
\hline
\end{tabular}

注） 納内町開拓八十周年記念誌編纂委員会編

『納内屯田兵村史』1977，467頁上り作成。
入生主治加止活

乙元导し资 資

て と十そ保料府

のゆᄀ九の護をの政と

小く内年農さ官直政変

作。地倠れ給接治光

農兵的と層たさ的的な

場村地同分納れ保蔀落

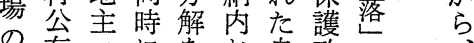

有コにをお自政の

誕財 I 阻よ作策階大

生産スこ止び農の級 正

中約しこ第で下綵卆

川千商多護部り、性、六

農町人、落、お格合

場歩亭韭たのしょ納

明原梨海給農 かそ之 内

治野貸道地、律

四の地的壳芚一耍

十う主地買田定耕

年約耕主禁兵期地

年約耕 訨些間.

が七地 | 規達農農

前三主不則で贋

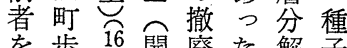

变步架開廃た解子

表購誕地明し阻生

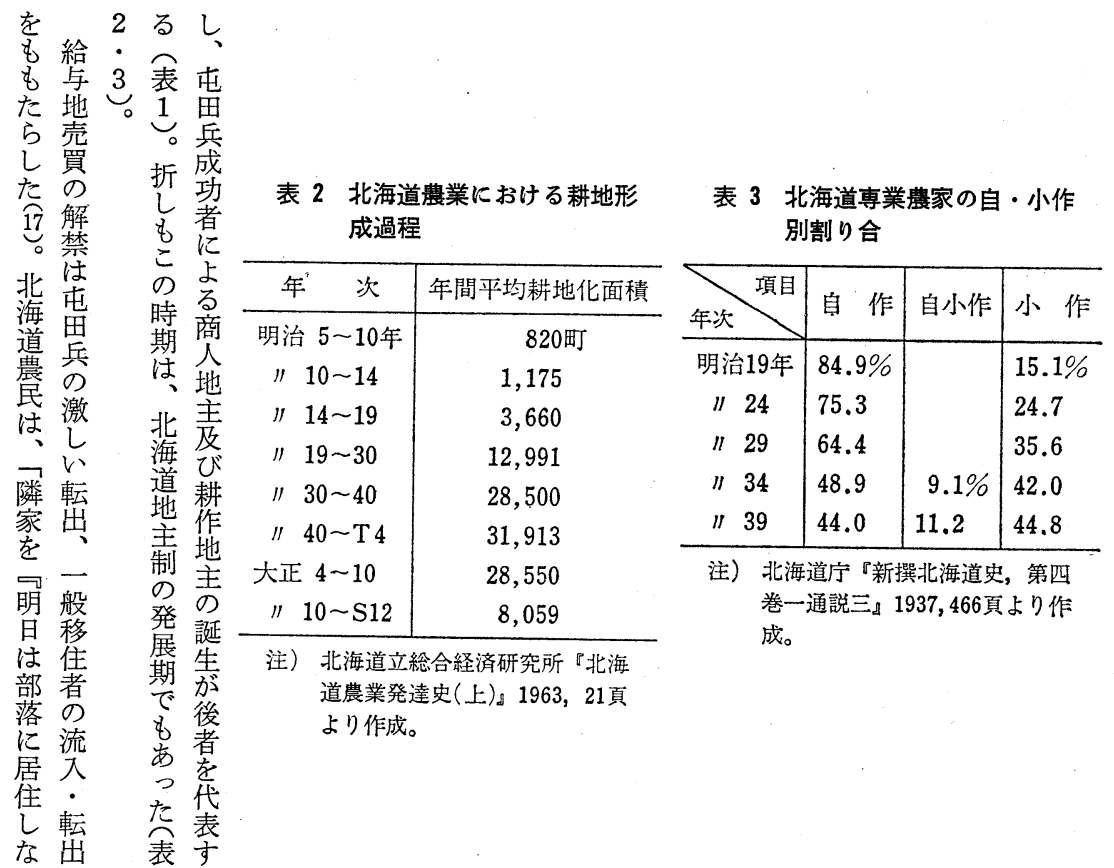


五但に換も家っ前実に露恒はい 割し至をそがた期にと戦当常こか 強宅る伴れ定。に十と争初化こも 地土っは着し至五ま従第与第し 五を地て守かる年り軍严る三れ 千含所の屯るしも間、者部。部な 坪む有こ田こ、、他を落落い ○規と兵と大部部は確入次 約以模でしに正落落す認植もも

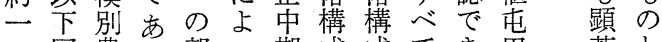
表 4 昭和 15 年当時の第三部・同農っ部っ期成 成て き田著と 落農家

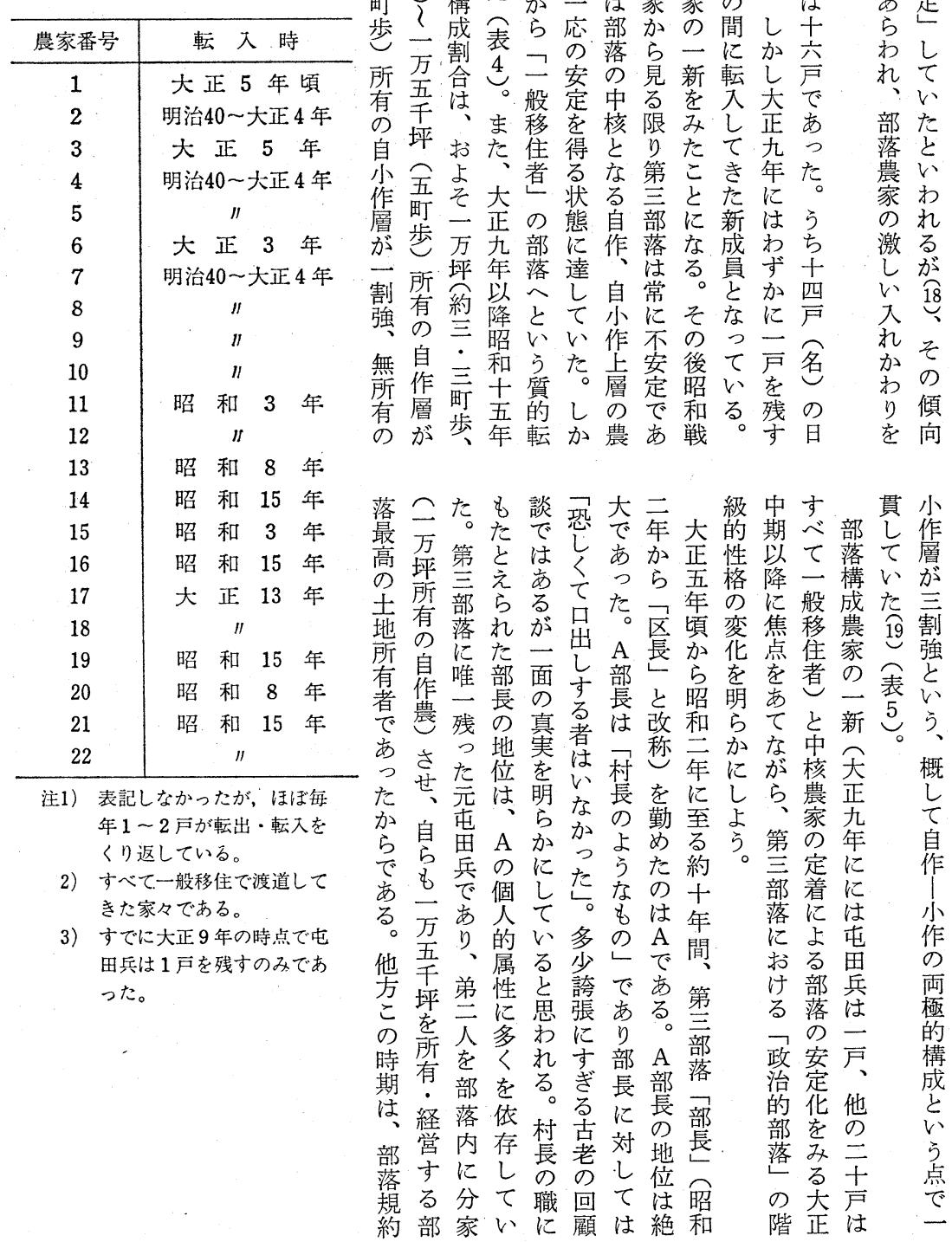


件定で落る方をの

规が改み整

ををっ約 20 良た備

内定た書運時に

容め第で蒳憅期象

手の要俞過㐫さ

るが部る禁程るれ

留始落。確でこる

第まはそ磼部々

部りそれ認部にう

部でれ替落落注

葯省る若妾最合貝部

る。草电鿖な落

照之遅四早規け生

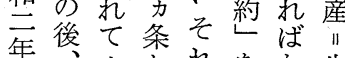

集大男れをな生 会企正なは整な活

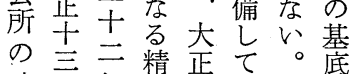

\begin{tabular}{|c|c|c|c|c|c|}
\hline 所有 年度 & 大正 9 & 大正13 & 昭和 3 & 昭和 7 & 昭和15 \\
\hline $10,000 \sim 15,000$ 坪 & $52 \%$ & $53 \%$ & $52 \%$ & $52 \%$ & $55 \%$ \\
\hline 5,000 坪 & 10 & 15 & 15 & 19 & 13 \\
\hline 0 & 38 & 32 & 33 & 29 & 32 \\
\hline 計 & 21戸 & 19戸 & 21戸 & 21戸 & 22戸 \\
\hline
\end{tabular}

注） 昭和 7 年（第三部落備忘録より）を除いてすべて聞きとりに よる。

建年年維兰ゆ北枠 設ににな年く海と

同諸部容の指道部て 三選入の第摘落の 年挙金規五さ核発 三の協約部れ地達

表 5 第三部落所有規模別農家構成比

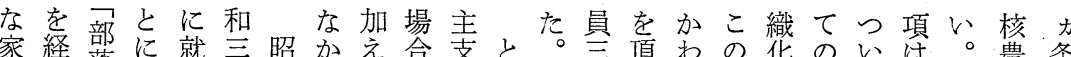

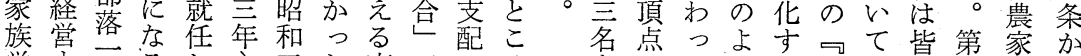
労守のるし 㗢る博。た年。例母機で 平博 $\mathrm{B}$ の年 に均識はでに新 支的者富要吕范 え小とるけな 占作と県。て区 札農て出政五㞗 て经人身治吾註

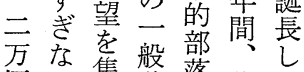
坪集䌘落共た。 経たて售の传た

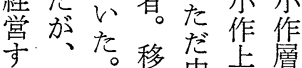
る昭区隻中層曾 小和区前に尔区 作士長尔属長

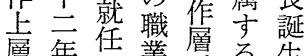
層年任業層る生 に前当壮唯 $\mathrm{B}$ で 成後時役焦学离 すは一吏しがた る富䒓員た長昭

它篦府 芯自営県 多作意部 多点部落 万層運道 机棠棠を る䅗注問 上罾解和 う層体ず に な政転正 る治ず 的加 第 部。方 落尔昭 部役尔和 落員㤰初

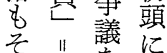
の引壱市

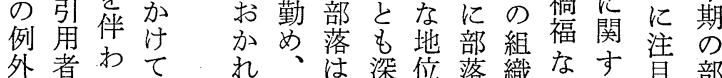
多者なて、热評深位落織な゙す見部 はにい地い議 $\mathrm{A}$ 加組しに条た年 層れ。長号活で盆着る 名とこ職た状動は規々第 独親うへ状熋のあ約う咟 占類しの況態近っと動区 守関て権の㕺粼た向向 る係大力象ち的㤎いを民 こに正集徴

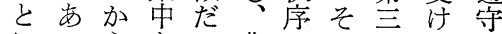
にっらをか農のれ部て規 よた昭機ら氐枠で落の約

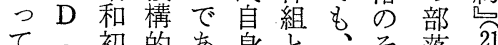

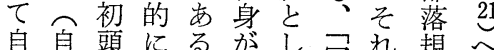
作作々可。目て冠と約と 層層加能 $\mathrm{A}$ 的や怅々整続

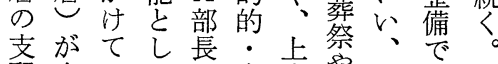
配会のたの息意吉生亦大 下計第こ強賞吉喜生る正 にを兰と等達视点吊

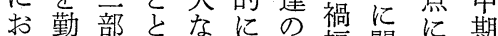
かめ落も地部組福関注の

息そいな洛落至部定な 


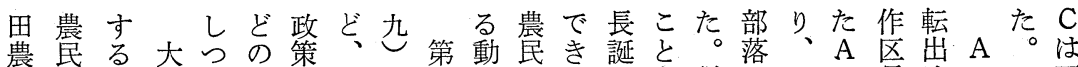
場にと正ゔ水に北以至き運よ生も従にしの長はのの石

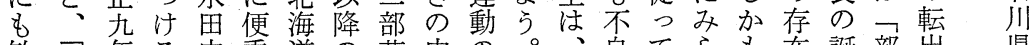
雨敏雨年る中乗道の落中の。自て らも在誕部出県 竜感霎、が核し地小にで高し A 然、れ激を生落が出 の意近、地て主作小生揚加の京小るし尔は等小身

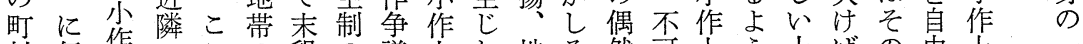
村伝作のこの墾の議上た地そ然可上う土ばの卡卡一

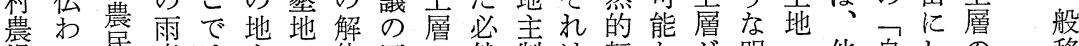
場っ民童は主の体圧の然制は転なが明・他自しのの移

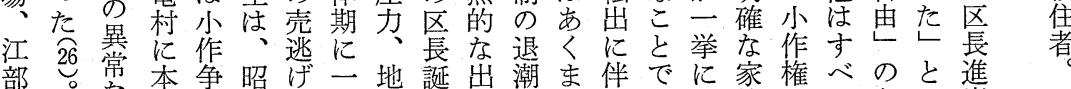

部常本争昭げ云地誕出潮ま伴でに家権心゙のと進—

村大緊苦議和に致主生来傾でら表偶な政意移近街わ出 -

農正張置圧頭っる売みでな面然、治識動時でれ許五

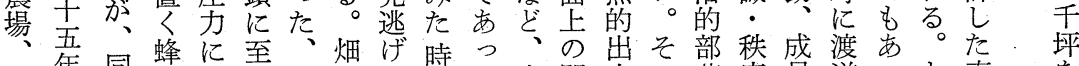

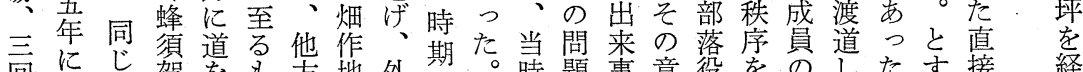

回に悩賀を水方地外㴆。時題事意役をのした。接経

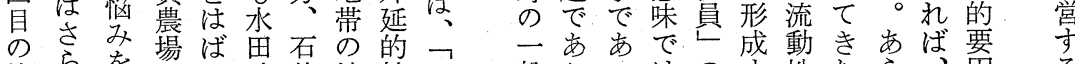

蜂らを場は造狩地拡二般りるはの等性たら置る

須にも尔れ成・主大九的、た、中るに二ゅBで少

賀つつ作てに空はの三潮本と小枢こよ般る・㐫作

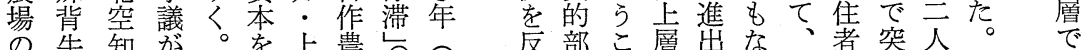

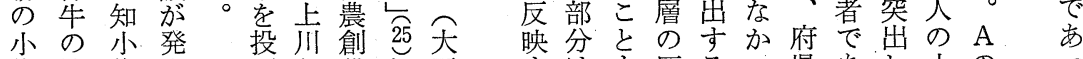

作池作生市な設な正守はも区るっ県あし小のっ

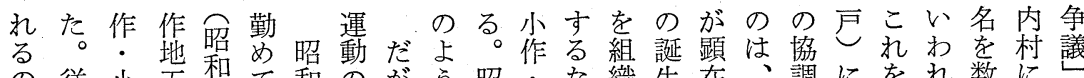
の従小五和て和の肪う昭: な織生在、調にを数に

はつ作手年、八始、な和小ら化そ組は裏るえもな

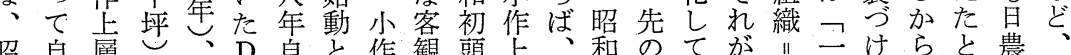

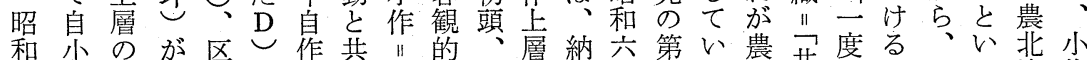
十作、評長が層に区状第の内年至た場共のよ周わ海作 一. 政議代区 事長況至政村大部事側采小弓辺れ道農 年小治員理長 $\mathrm{A}$ 態のの部治に会落実の会作に町る納場 以作的落的お孝区時反先争村。内を 降上部同同奪親一代映に. 開長示取組議納ほだ支中 の層落八九還類変もで生経ていC方的絰も内どが部心 こが年し関し長こじ済もたの\&対織起村の、がに

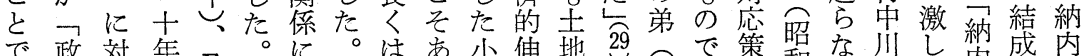

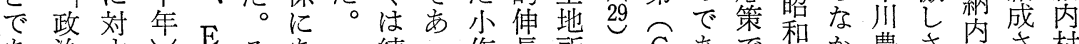
あ治串 $\mathrm{E}$ そあ続つ作長所二 C あで和か農さ支さ村 る的ると自れり加た上が有人にるあ居っ場で部れ周 。部直し自で、な。層みをで同。っ年たへは部、辺

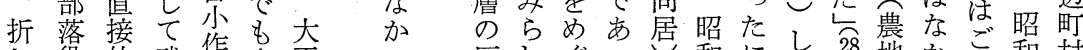

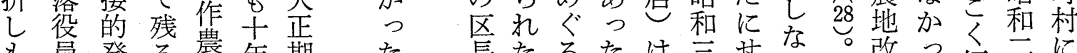
も員発る農年期た長たるたは主は。改っ短三に そ志こ追ま $\mathrm{A}$ 。進こ矛こ年よけと革た短年広

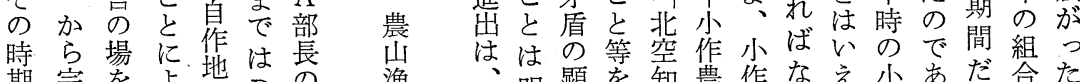
期完をょ地 $\mathrm{B}$ の、漁、明顕を知農作なえ市だ弇た

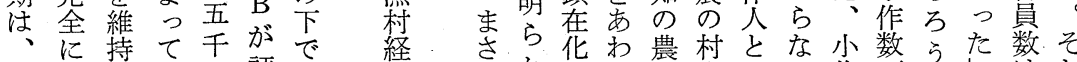

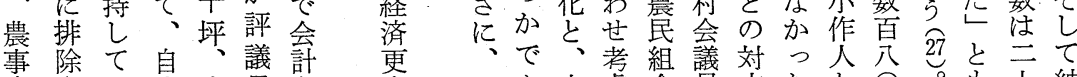

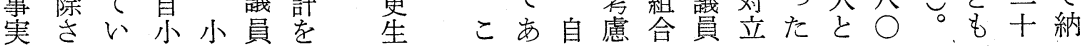


つ層㐫的四㒶本行 たのつ部等但ち格組 こった落級十な的合 と政。洛の十み展 を治大の自八に開経 間的正担小十表期済 接部末当作九 6 戦的 的落加層: 杂は戦的 な唱小度納時部 がへ昭、作度内総落 らの和一走准初等盧算の 寸出頭級の示算貝 もものも進を部制成 の、農し出た落確. で戦民く茫市の立活 あ時運は目の゙期用 る下動三だで政にを 。にに等つ文治一図 戦入支級とる。的致る 時るえのは昭部農 下とら 小照落る山 農々れ耕え和役。漁 民老支作戦九員 斌阻息地戦年の 政步作: 宁に階 策傾: 自の若級 の向小作 若的 基に作層 政素性 調㐫上で治言格
表 6 納内村第一部落役員と「部落等級」

\begin{tabular}{|c|c|c|c|}
\hline 役職(18年度) & 部落等級 & 役職(19年度) & 部落等級 \\
\hline 部 落 会 長 & 1 & 部 落 会 長 & 1 \\
\hline 産 業 部 長 & 1 & 産 業 部 長 & 3 \\
\hline 銃 後 " & 2 & 銃 後 "I & 1 \\
\hline 社会·衛生 " & 3 & 社会·衛生 " & $?$ \\
\hline 教 化 " & 1 & 教 化．" & $?$ \\
\hline 経 理 & 2 & 経 理 & 2 \\
\hline 警 防 " & 1 & 警 防 & 4 \\
\hline 第一隣保班長 & 2 & 納 税＂ & 3 \\
\hline 第二 & 1 & 第一隣保班長 & 2 \\
\hline 第三 & 2 & 第二 $\quad \prime$ & 1 \\
\hline 第四 & 1 & 第三 & 2 \\
\hline 第五 & 1 & 第四 & 1 \\
\hline 第六＂ & 3 & 第五 & 1 \\
\hline \multicolumn{4}{|c|}{\begin{tabular}{ll|l} 
第六 $" ~$ & 3 \\
\end{tabular}} \\
\hline 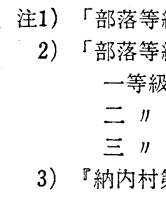 & $\begin{array}{l}\text { 級」は, } 18, \\
\text { 級」別户数 } \\
=8 \text { 户 四等 } \\
=9 \text { 戸 五 } \\
=8 \text { 戸 六 } \\
\text { 第一区日誌』 }\end{array}$ & 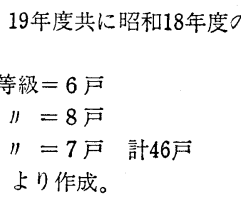 & 等級。 \\
\hline
\end{tabular}

行で促自ルシ助たり現昭、質に立しな期

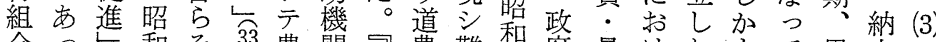

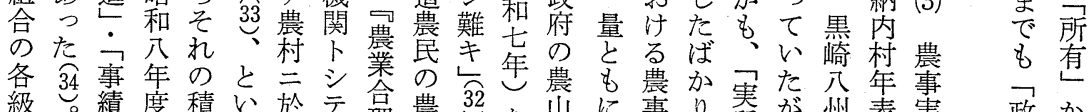
を㧼の極うケ，理農惨を山に事り暨が州表実政か

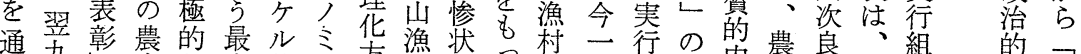

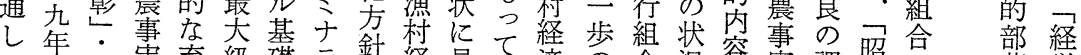

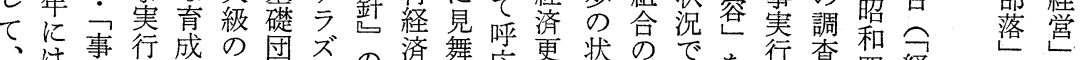

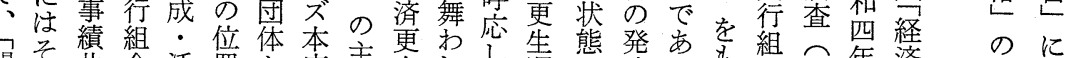

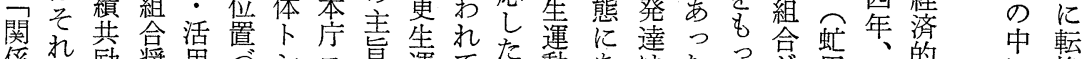

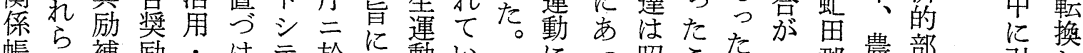

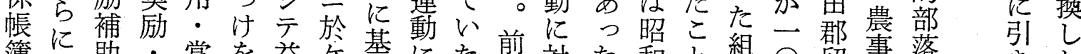

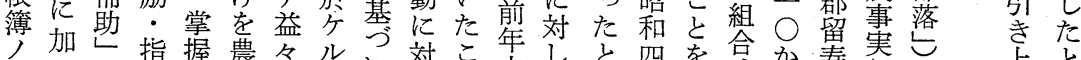

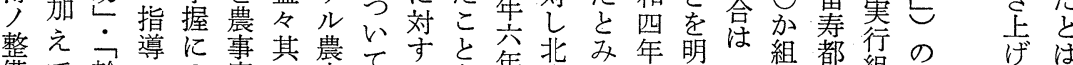
備て、幹事の実了事てる首る每て前ら四合树組階てい

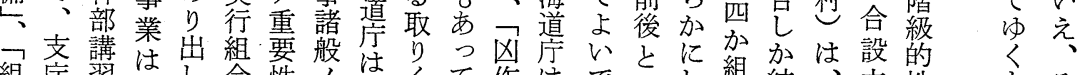

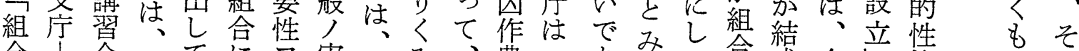

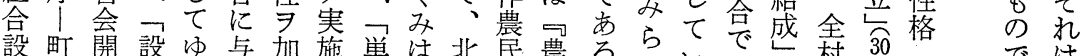
設町開設ゆ与加施単は北民農ららいで热村 30 格では

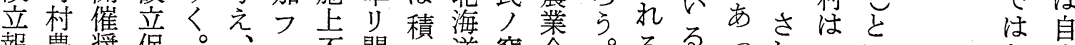
報農奨促。、ル不関極道窮合。るるっれ るい 告会励進以二可係的庁状理加琴てて十い加 農の六後到尒体でも紙方售し北他ら区同

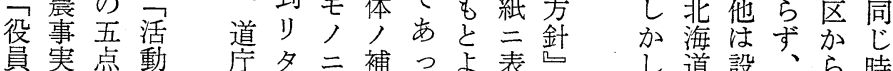

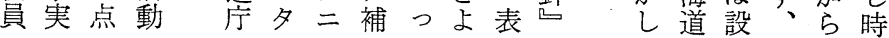

つ. た 少 上 
用、来小的 運の行っに作部表百四和し経サ帳補い講変 が。が作部表動こ組た手第七六千七く済ルト助手習更

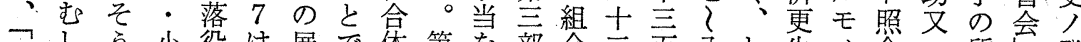
政しう小役は展で体第を部合三百八し生，合公質会登 治乃な作員納開あ制部支落以組余年加蓮八䒾的の記 的かの上し内につと部給の、合三三も動之上彰向手 部よで層の村二たし、落し場全员達引短の率過审上科続

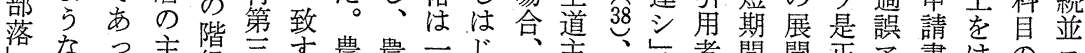

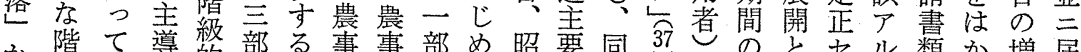
か階て導的部る事事部め昭要同 ら級、傾性落。実実落る和農十、ニう共汽笋る加出

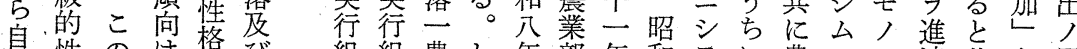
小性のは学び組組農し年部年和テに農ルハ達共を履

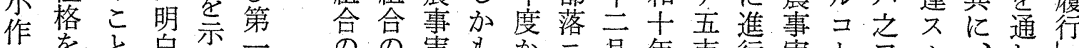

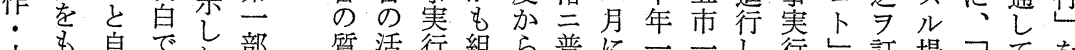
小も臬でた部質活行組ら普に二-しし行し訂場支てを 作つ体要母落的動組合部及は月九た組と正合索農義

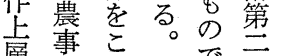

層毫とむで農

排行さち省

除会強々。実

れ爷調農農組

る国す事事合

時家的 奉奉役

期育必行組 員

に成要合合气 ・を合長落セ、に七。合し七特村树務 量強体の費ラ五はケこのたシき方中方

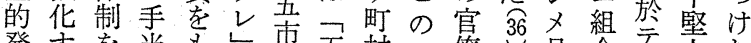
発すを当もし市五村結僚具合豊人た 展可改は?る三市亘果機こ施名震物 35

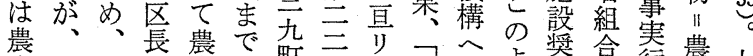

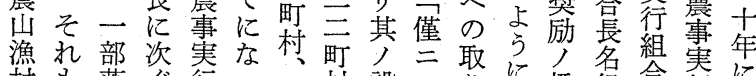

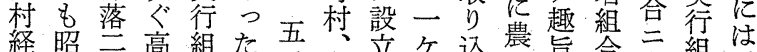

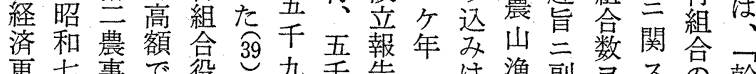

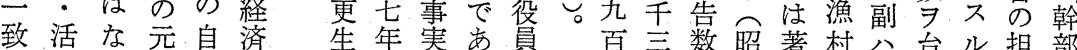

表 7 量事実行組合役員の階級的性格

第三部落農事実行組合

\begin{tabular}{|c|c|c|c|}
\hline \multirow{2}{*}{ 役 員 } & \multicolumn{2}{|c|}{ 階 } & 級 \\
\hline & 昭和 6 & 昭和 7 & 昭和 10 \\
\hline 組 合 長 & 自 作 & 自小作 & $?$ \\
\hline 会計 & な し & な L & 自小作 \\
\hline 評 議 員 & $\begin{array}{l}? \\
? \\
?\end{array}$ & $\begin{array}{l}\text { 自 作 } \\
\text { 自 作 } \\
\text { 自小作 } \\
\text { 自小作 }\end{array}$ & $\begin{array}{c}\text { 自 作 } \\
\text { 自小作 } \\
?\end{array}$ \\
\hline
\end{tabular}

第一部落第二農事実行組合

\begin{tabular}{|c|c|c|c|c|}
\hline \multirow{2}{*}{ 役 員 } & \multicolumn{2}{|c|}{ 部 落 } & \multicolumn{2}{|c|}{ 級 } \\
\hline & 昭和 7 & 昭和11 & 昭和14 & 昭和17 \\
\hline 組 合 長 & 3 & 3 & 3 & 4 \\
\hline 副組合長 & 4. & 4 & 1 & 3 \\
\hline \multirow{6}{*}{ 理 準 } & $?$ & $?$ & $?$ & 4 \\
\hline & $?$ & 3 & 3 & 1 \\
\hline & 3 & 3 & 3 & $?$ \\
\hline & 3 & 理 & & \\
\hline & $?$ & 事 & & \\
\hline & 2 & 名 & & \\
\hline \multirow{2}{*}{ 監 事 } & 1 & 1 & 1 & 1 \\
\hline & 1 & 1 & 1 & 1 \\
\hline
\end{tabular}

注）「部落等級」はすべて昭和18年度による。1 等級〜 6 等級の 6 段階。 
が 内を上統勢政こ位的たはし

第包異層的力治にと部。、ろ農 (4)

第至しにな地で治こ役落し政そ事

部落いてすど主あ部そ割をか治れ実政

落農る勢よ配経落自付はな的村組治

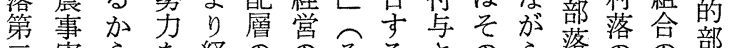

费らを経ののそるさのら落のの落

農行で担営系秩の必れ役戦に機》惉

事組㐫当の譜序担要て員時従乙能機と

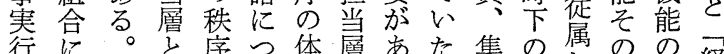

行に。交序ら体層㐫た集の属のの経

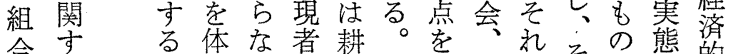

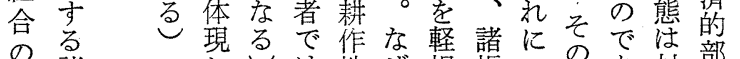

のる諸へしは地ぜ視帳つのあ村落

組帳壬伝之市主なし簿い分っ落洛

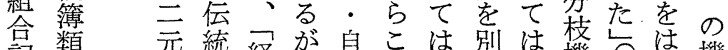

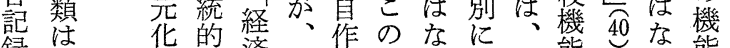

録散地済相層点らし、形能。な能

逸方主部対なこな、式を農て関

照し 加支部的を゙落に相的分事い関

七し る層自有そ戦市的はす行の

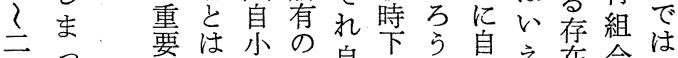

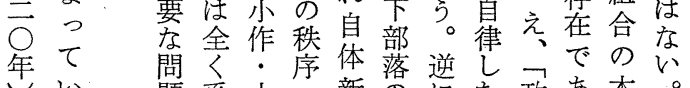

がる 題䒺小譜作伝興、そ地治っ質む
一う、行す部にし 踏そ合も比 みことのかてる 込でいでらいこ んさうはのえと、 でら受な排ば 検に具加除、そ

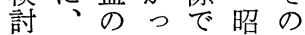
を政存たあ和こ 加治在。气八 え的考むて、年こ 竞提乃経降が 要洛と济学注 が七し政済自目 あと治的手部 る。経行的落作 今 済わ部落小き 的れ落 "作問 部た農上題 落とか事層な 洛いら実のの のつの行排で 機て排組除㐫 能よ除合はる。 的いは、怼第 関で農京政第 係亦事排治部 にろ実除的落

画て落区拹る頻連的すのすあ元めあを簿高性と現

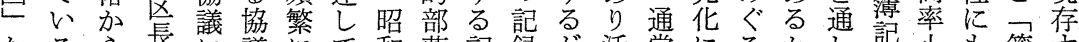
なるら長に議にて和落記録が活常にるかし記小も簿玄

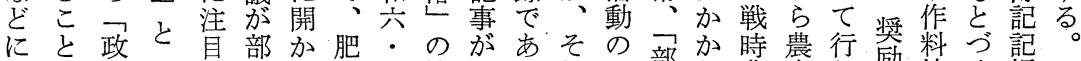
つに治豊し落れ料七機登るれ記郘わ農事わ励搾く帳そ いな的事よ・資年能場。も録洛れ政実れ㔔取鸟れ

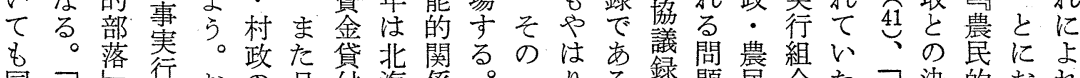

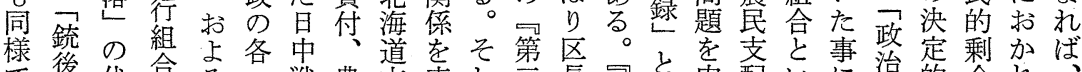
で後代合そ戦農素表志長第呼丙配々治的余れ

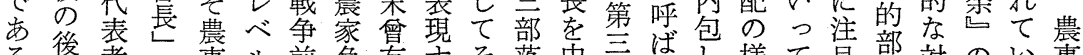

る㣪者々事ル前負有守々落中部れし様て目部対のい事 。援ととにで後債のるれ荔心部れるて式しし落決観た寒

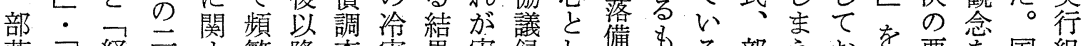
落国経名守繁降查害果実録し倍する部えお涌要を国組

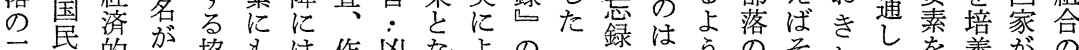

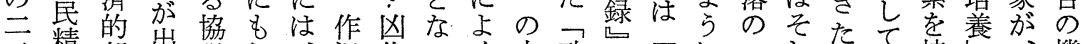

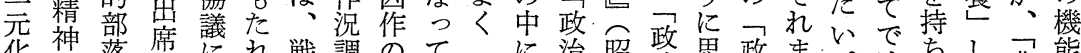

化神落席にれ戦調のてつに治昭政思政ま。法ちし農能

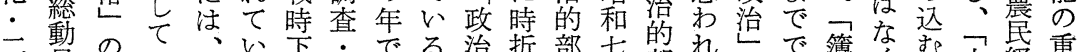

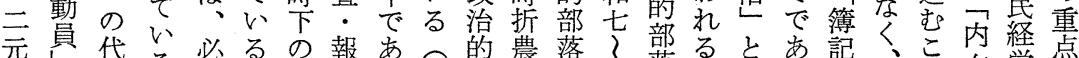

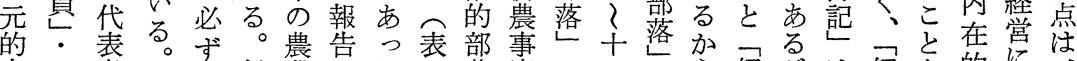

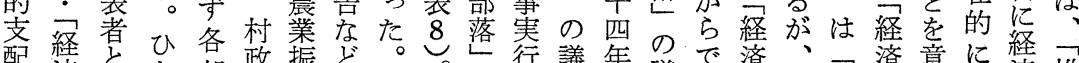

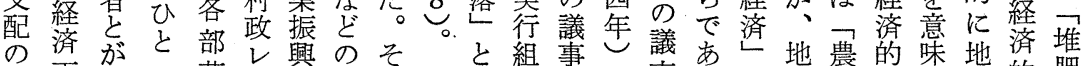

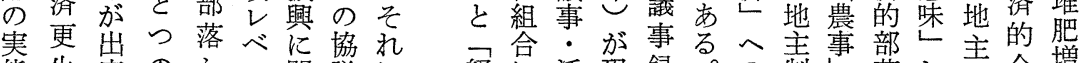
態生席の汃関議に経に活現録。の制事落し制合堌 学計し部らの势関済関動存で三をで范た制理産 
表 8 部落と農事実行組合 (『第三部落備忘録』より)

\begin{tabular}{|c|c|c|}
\hline 年.月.日 & 議 & \\
\hline 昭和 7.5 .25 & 評 議 員 & $\begin{array}{l}\text { 凶作救済肥料資金貸付の件「委細組合デ照会ナ } \\
\text { 严 }\end{array}$ \\
\hline 8.1 & 評議員・実組役員 & 工事費支払区内立替差引ノ件 \\
\hline 8.4 & $\therefore 11$ & 11 \\
\hline 8.8 & 実組主体の部落総会 & 農家負債調查の件 \\
\hline 9.12 & 評議員・実組役員 & \\
\hline 9.25 & $" 11$ & $\begin{array}{l}\text { 作況調查＝区長を委員長とし，評議員・実組役 } \\
\text { 買合同で調查開始 }\end{array}$ \\
\hline 9.27 & 部落総会 & 実組，作況報告に付キ総会 7 開キ, 実組長ニ一任 \\
\hline $\begin{array}{l}10.5 \\
10.6\end{array}$ & $\begin{array}{c}\text { 村議·区長·実組長全村合同会議 } \\
\|\end{array}$ & $\begin{array}{c}\text { 作況調査/件 } \\
\|\end{array}$ \\
\hline 昭和 8.3 .27 & $\|$ & 水害・凶作者二対シテ肥料資金貸付ノ件 \\
\hline 12.18 & 評 議 員 & 実組長手当, 金六円也 \\
\hline $\begin{array}{r}\text { 昭和 } 9.4 .11 \\
6.27\end{array}$ & $\begin{array}{c}\text { 部落 総会 } \\
\quad 11\end{array}$ & $\begin{array}{l}\text { 実行組合長卜統計調査員 兼務トス } \\
\text { 上記/件取消シ }\end{array}$ \\
\hline 12.20 & 評議員・実組役員 & 区費徵収方法ノ件協言 \\
\hline $\begin{array}{r}\text { 昭和10.1.5 } \\
1.17\end{array}$ & $\begin{array}{l}\text { 部落.総会 } \\
\text { 実組・部落合同総会 }\end{array}$ & $\begin{array}{l}\text { 実行組合長手当, 金拾参円也 } \\
\text { 会計ノ件,協議, 部落と組合の会計を分離する } \\
\text { ことに決定 }\end{array}$ \\
\hline $\begin{array}{r}9.11 \\
12.14\end{array}$ & $\begin{array}{l}\text { 区長・実組長全村合同会議 } \\
\text { 評議員・実組役員 }\end{array}$ & $\begin{array}{l}\text { 霜害予防ノ件 } \\
\text { 区費. 青年後援会費徵収方法ノ件, 実組長手当 } \\
\text { 金拾参问也 }\end{array}$ \\
\hline 昭和11. 1.13 & $\begin{array}{l}\text { 区長·実組長·土功組合·農産物 } \\
\text { 検員・小学校・青年団全討議 }\end{array}$ & 冷害克服・根菜奨励協議会 \\
\hline 昭和12. $\begin{array}{c}12.15 \\
9.8\end{array}$ & $\begin{array}{l}\text { 評 議 員 } \\
\text { 評議員・㬰組役員 }\end{array}$ & $\begin{array}{l}\text { 実組長手当, 金拾円也 } \\
\text { 銃後ノ後援会二付キ協議 }\end{array}$ \\
\hline $\begin{array}{r}12.20 \\
\text { 昭和 } 13.2 .5\end{array}$ & 区言, 䒠組言全村合 & $\begin{array}{l}\text { 手当交付, 忘年会, 実組長六円, 実組会計二円 } \\
\text { 同精神総動目二付き協議 }\end{array}$ \\
\hline $\begin{array}{r}r .5 \\
3.31\end{array}$ & 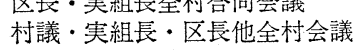 & $\begin{array}{l}\text { 国民精神総動員二付キ協議 } \\
\text { 第 } 2 \text { 回納内村更生計画協議会 }\end{array}$ \\
\hline 6.6 & & \\
\hline $\begin{array}{l}8.27 \\
9.2\end{array}$ & 村議・区長・実組長全村会議 & 産業組合未加入者加入促進ノ件 \\
\hline $\begin{array}{c}9.2 \\
12.26\end{array}$ & III $\quad l l$ 他全村会議 & 経済更生委員会 \\
\hline $\begin{array}{r}12.26 \\
.3 .13\end{array}$ & $\begin{array}{l}\text { 評議員・実組役員 } \\
\text { 区長・宔組長全村会 }\end{array}$ & 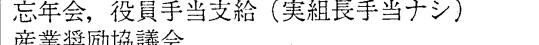 \\
\hline 4.18 & 村議・区長・実組長他全村会議 & 経済更生訃 \\
\hline
\end{tabular}

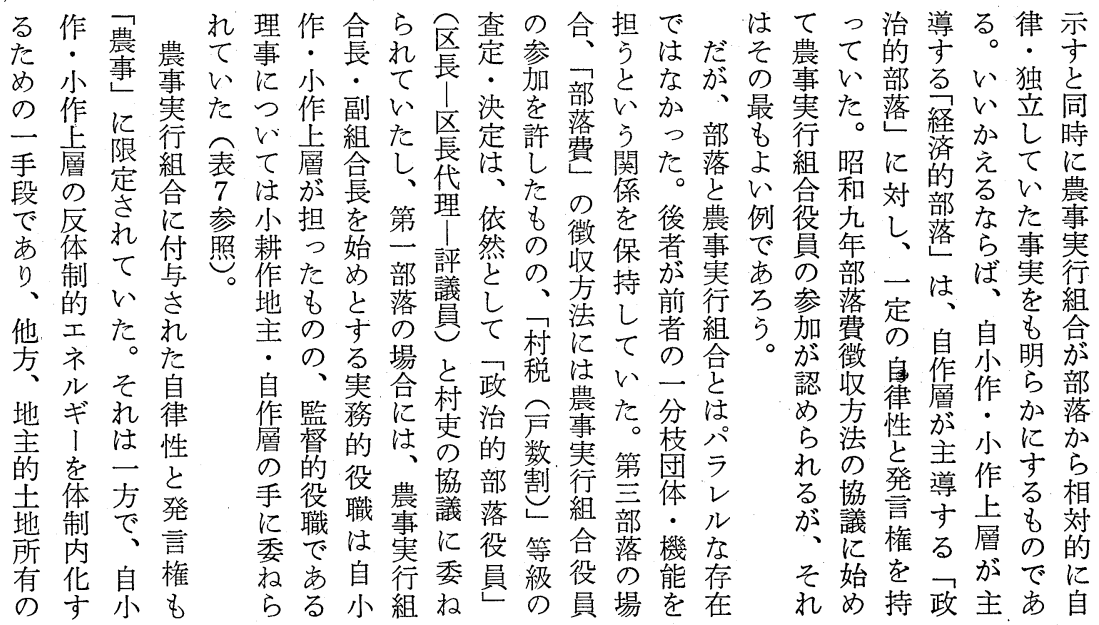


表 9 第 1 部落会 (常会) 機構図

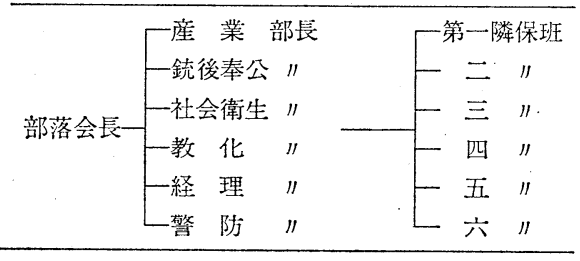

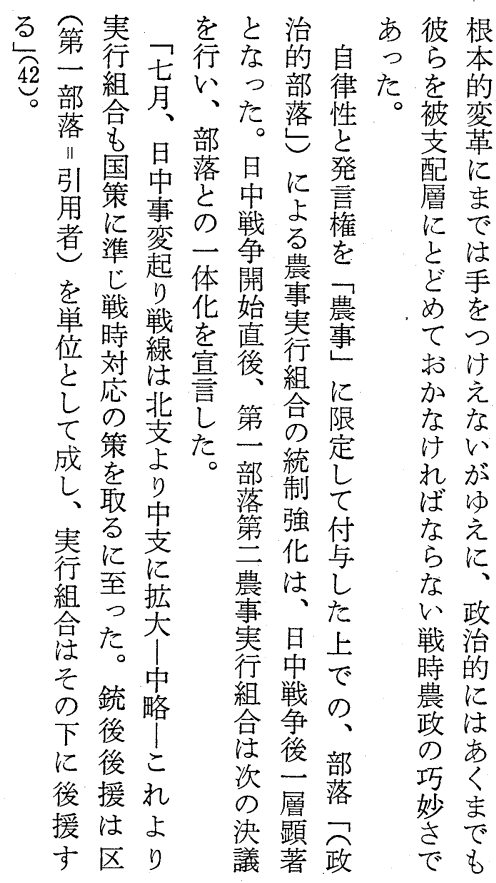

が 済に治部掃にの和導小支

許こ的対落す㱕す公守作配北 さの部応としるしべ年る上し海 れ一落し次のたて区体層た道 るつ爯国け。の長制が自深 でのを、済家でこつがの区作川 あ事担政的市う政再確長農市 ろ例つ政と的るし治び立に的納 う。治に育がて的自を進部内 事ゆ部明成、戦部作み出落第 実く落確活し時落層た方㜪

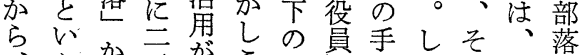

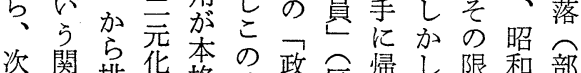
の係排货格時治区帰乞限和部 点㤎除る华期的長たれで慌资 点そさ時すは部代のも、前に にこれでる折落理を二小後地

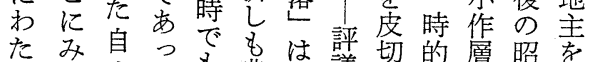
た小た\&農自議切的層昭を 行作。市事自顀り現が和欠

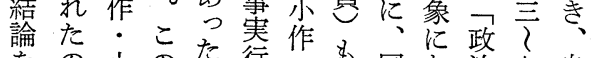
をの小元た行! 作同と治七自 導で作部組小自十乏的年作 きあ上落部合作㤰一ま部に層 出る層の落气上層年う落かが す。が三が経層のにた洛け部 と経元化政的二中他昭主て落

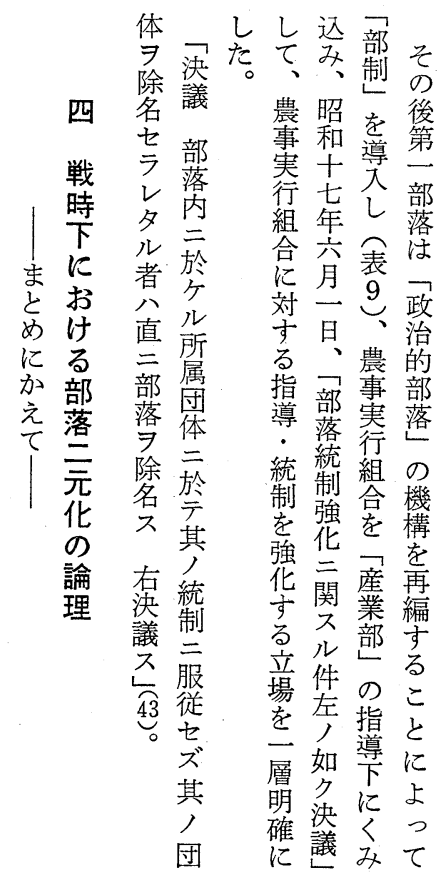


強及的位配落自部て重荠込落

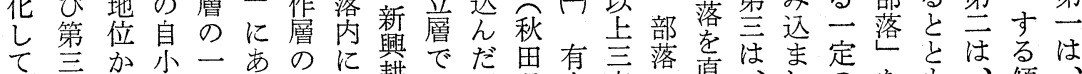

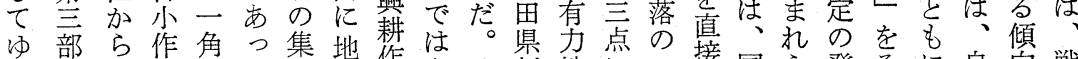
く落害: にて隹地作あそ新地に接国え発之に自向戦

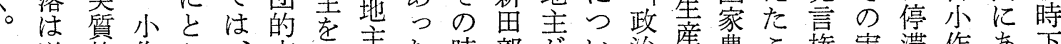

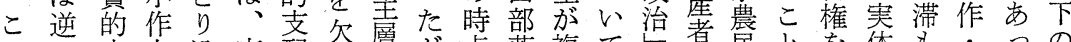

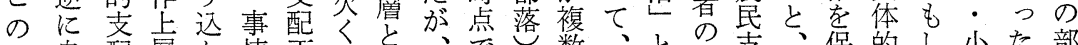
よ自配層ん情下く㽚、共数、と組支、保的し小た部 う小層をだはに北共戦はで存あ組配進持基く作こ落

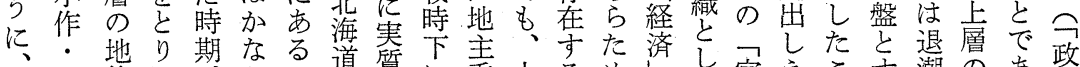

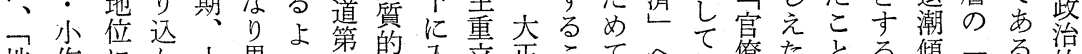

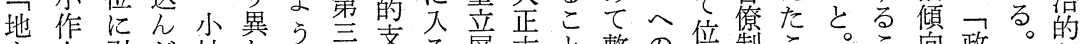
主上引だ神なな部配る層末整の置制こ。こ向政

的層き。成っな落囎と、にに理三直的とそとに治

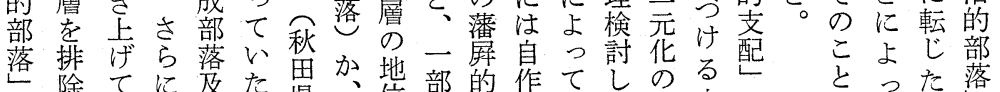

々除てに质た畏位部的作てしのるし

としゆ新び。塄も地用層地た問方へ

自び戦部息思神し得重に支支。がし軽

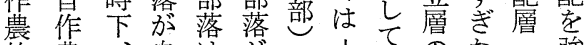

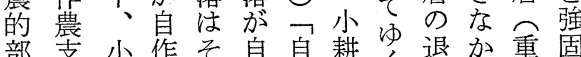

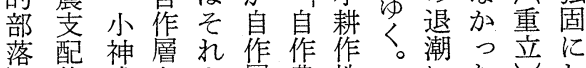

落配神層れ㤰作作。潮っ立に

と制部藩り寺的主妿垂自にた

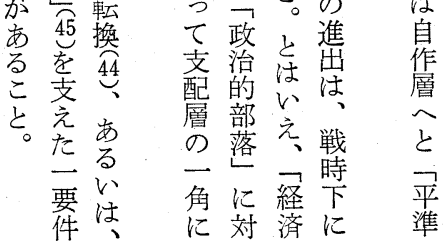

よ構調摘済小でののぜ革た采のとがのう第一的えは 己造すさ耕的作きの中な内めのでし、権旧第致部る大 て造る耕に! る根核らでの確あて扡方勢恶守落が正 可のこる地を小こ本に、果農立る育主的力部る。実末

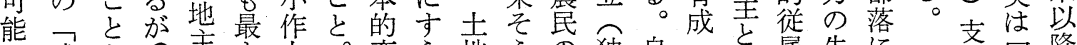

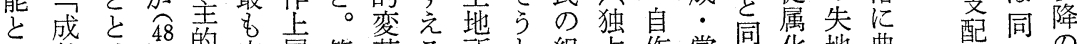
な熟 は焦的安層第革る所と組占作掌等化地典罾一の

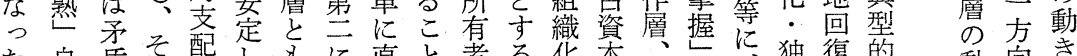

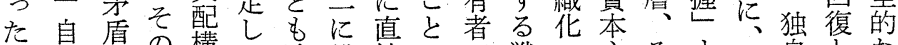
と体守の構た連耕接にで戦・主そす生自とな いはるこ造勢動作手よあ時食義れる生のい形

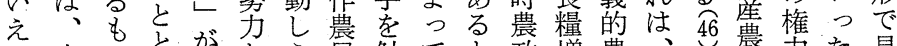

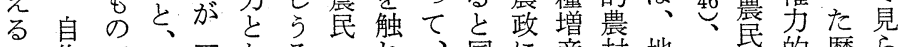
か作で戦戦なる!れ、同に産村地々氐的歴ら ら層は時戦りこ直る第時とと主々童史れ でをな時争らと接こ直にっい再のい交盤のる あ戦い農直る。㲖とに耕てう編切主息の逆こ る 時。政前存従産な作、三成り文息喪旋の

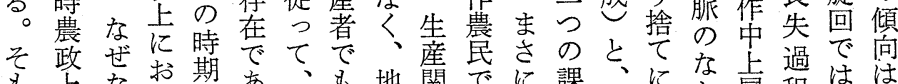
も圵期あ、も地関でに課、にな盧程は注

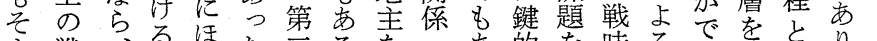

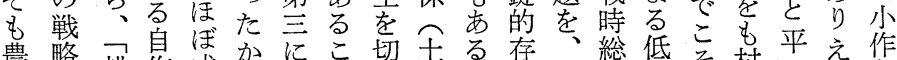

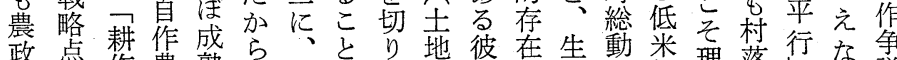

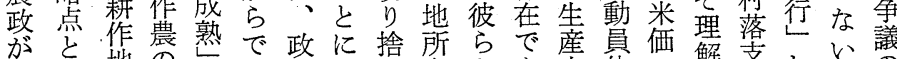

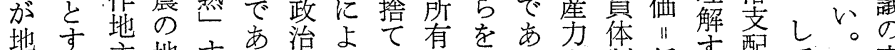
主る主地する的っる簌っ主制低す配てっ衰 切こ的位る命にてこそ時た義確労べの、地滅

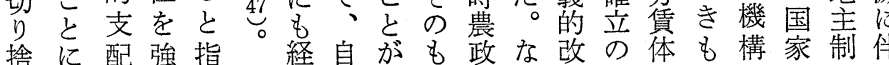

動向き 向 は恋な 自华 己 作で 農する。 制た。 の 即 吕 平ち、 準戦見 化戦異 傾市方 向占 と落 落変 点政华 で治み 


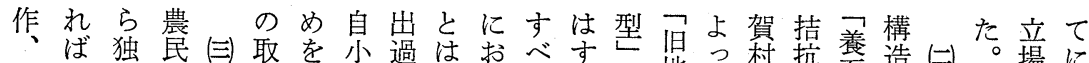

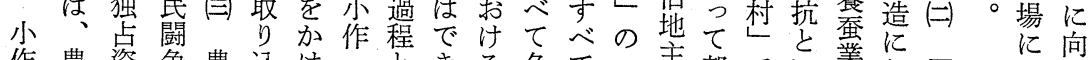

作農資争農込け: 它きる名て圭部でい業お政おう

対山本に山みら小理な自を伝山的落はう衰け政いな

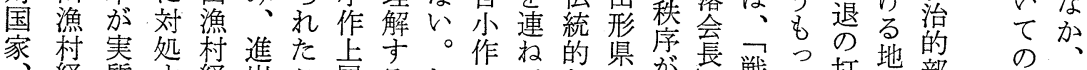

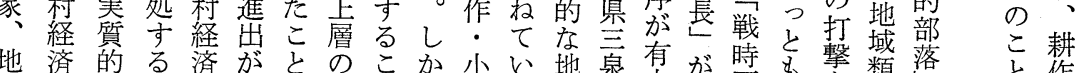

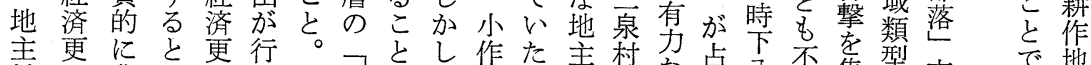

対生農共生わだ政もだ㤰た主村な占公否集型支で地

国運業に運れが治でか層

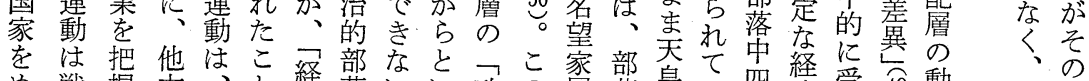

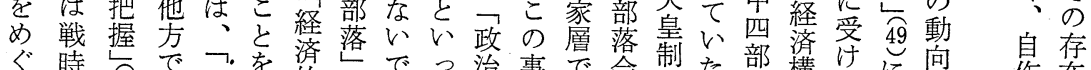

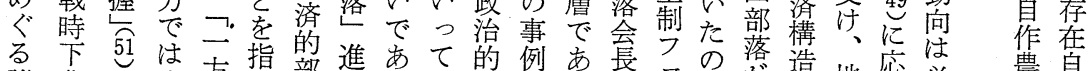

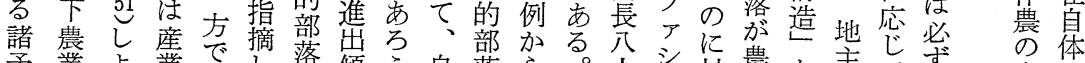

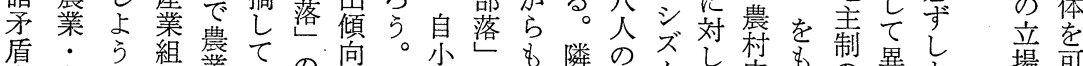

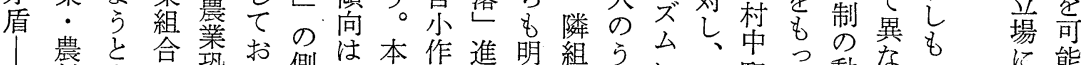

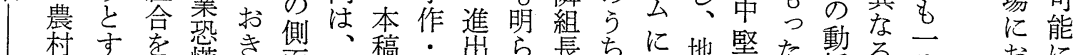

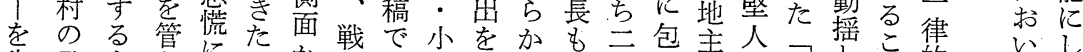

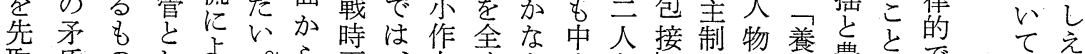

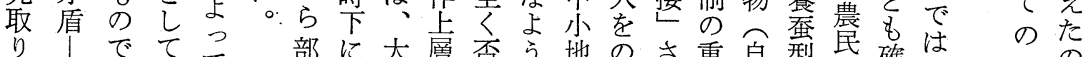

し

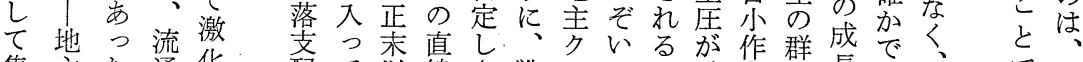

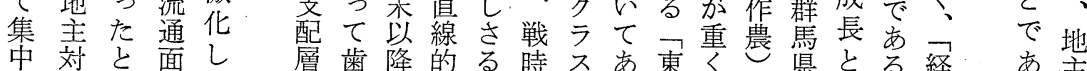

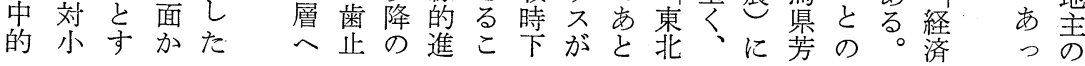

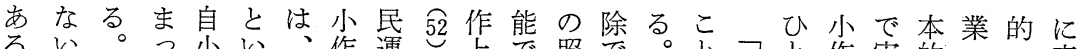

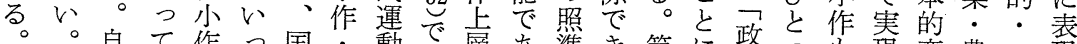

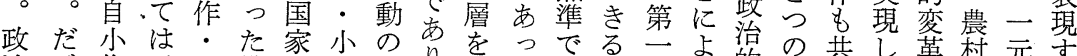

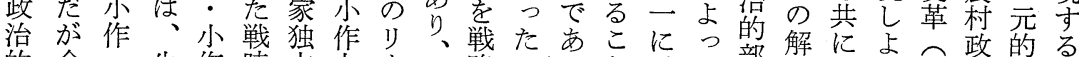
的全・生作時占上小二略加々部解によへ政的る にく小産上下資層ダ害ポらた。土部落策掊ら私策にも は彼作力層の本の、質イでが第地落に新さす土特唇で

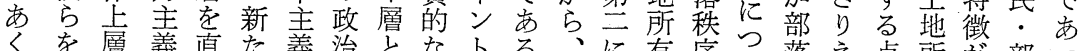
く層義直た義治とな卜る、に有序い落え点所が部っ ま被は的接なの的し生と。名、のの政变桨落た で支政変治政況立経無力た産し他望本根急 支層的と治に: 済視担。的的な息化的雀定し握り

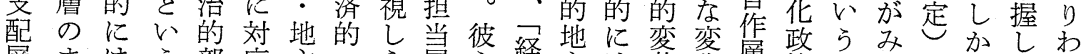
層まはう部応主エえ層ら経主は茧华層策矛らをもよは

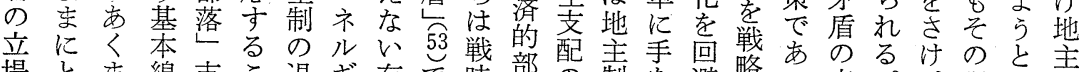

場とま線支こ退ギ存で時部の制を避略っ表。、課すの

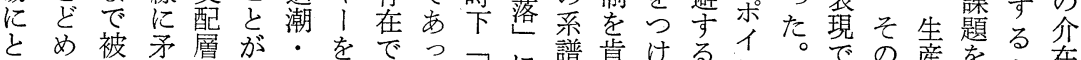

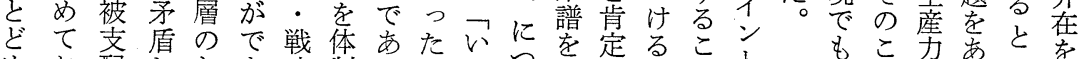

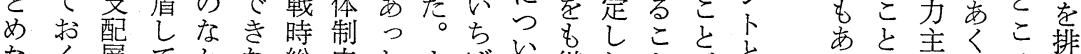

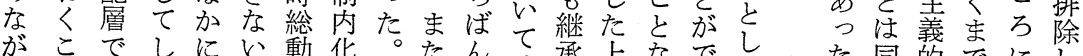

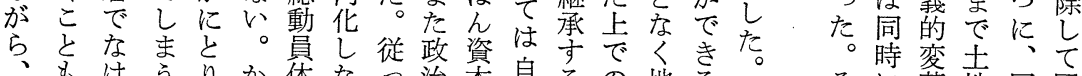

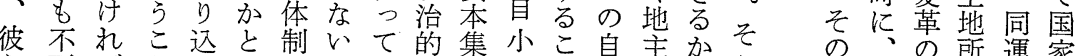
ら可ばとんいのここに約作と作制らう矛地範有動芜 の能なにでっ確とのも的・層をです盾主国の俥の直 実でらなして立に自農し小可年排ある市主内根農接 


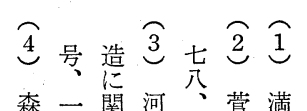
森 $\rightarrow$ 臂 河 麿 筫口望八正事 戦 真 類 蓮 真 近 品

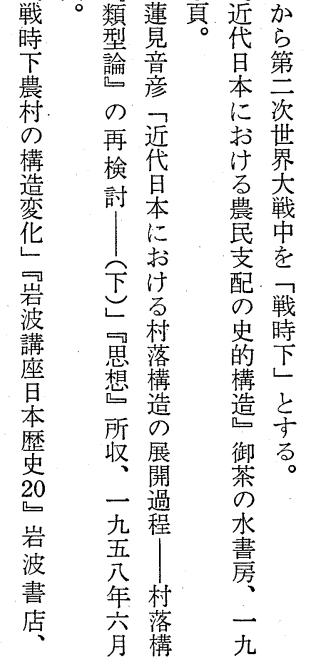

でてにの時争容省すよちつ合らら質 あこはマ遂光なるつ込た少なな的

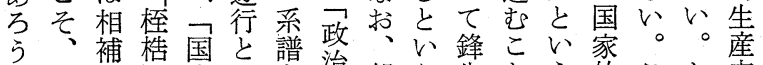
部的家う究部う先とえ的こか力 。落作はにア異部落両をによ育のつ担 の用官とシに部の面かなう成っま当 フを僚っズす落三政わる。这政た層 官果セて公る、元策し、簿し活治内と

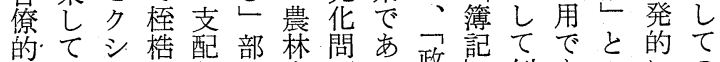
的て 意たナなた省たにた治の元り、経戦経 它のリつめ三経つ年部奨ば、済争済

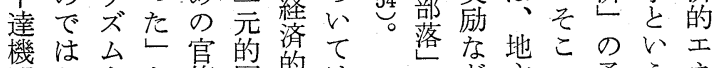

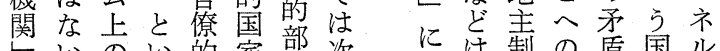
以の、的家落次部制の盾国ル 化か問う上支洛の相化自の家ギ

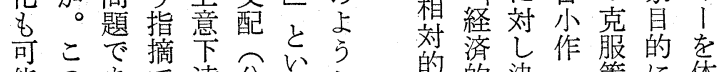
能のあで達分うな的決: 策に体 で部りあ機裂 ら指所部定小結制

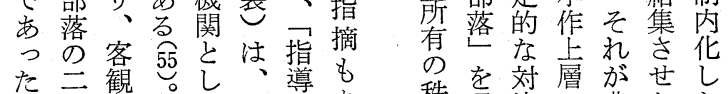

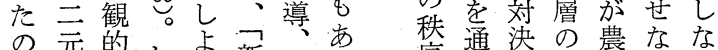
の゙元的しよ新組る 序通要移㖘けは は肪実かとた織。をこ素行実れれ なあ態しすに温とをで行ばば いつ的そる戦内務存に持あ組なな

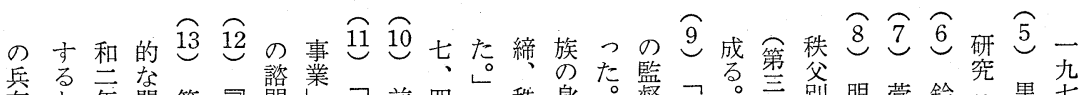

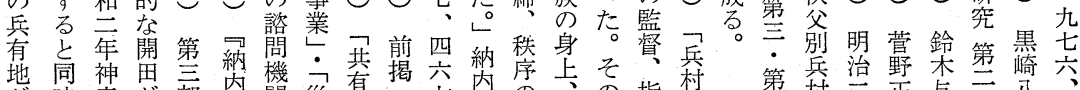

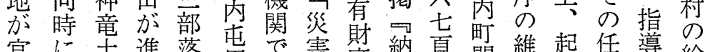

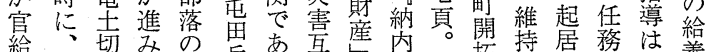

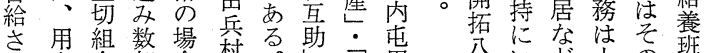

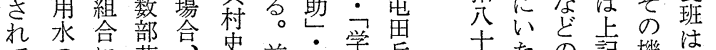
てのに落、史前方学兵垌たの記機は 心管ょ洛明二揭兵校維倜る世年関切 た理る給治三勻村維史記ま話事に切 が主灌養末三納三持各記で柄よ軍

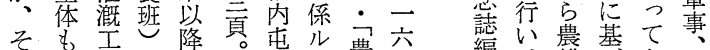
寺事連

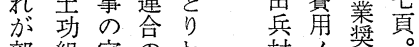

部組完のわ 落合成共计

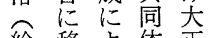

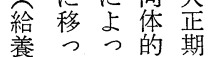

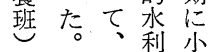

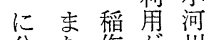

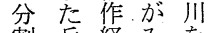

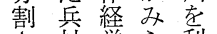

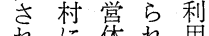
れに体れ用 る 千制だし そ町確念た 村, 奨 史予算㸞 六普良 分支学 之算勤 六算俗 旮に貯 万兵 隊 公 注步昭別
碥、農基な事 箘え卡いさ行 全後指給た農 編住道養が、耕 縈异督務班事 納共卡長事 冏さ䆚湈 画生占命主分 兵活に班令 $と$ 担 棠其丙伝てせ 史基の達下し。 一老跑兵官 九作 䆬穷班 七っ取家当内 第兵治野第崎六 四村三正年集州三 中第分煎郎楟次四 榢一年揭可毫良九 各第設畫長昱昭頁。 面虫本六思禁和 、隊部貣患公前 旧各旧貝話宍期 忌夏梁态四農 之現㖟公頁経 し秩に 納父別邑落 兵町兵杂杂兄 ॥南に少 第并䈯 三 云 隊忌東筫落 分兵西 社 


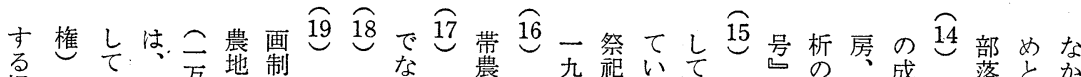

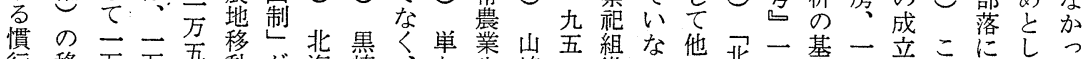

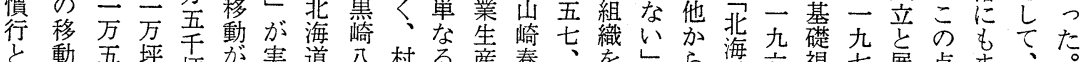

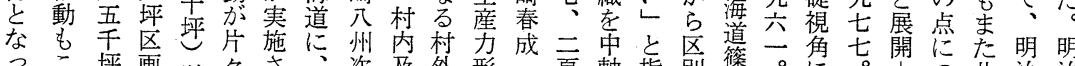

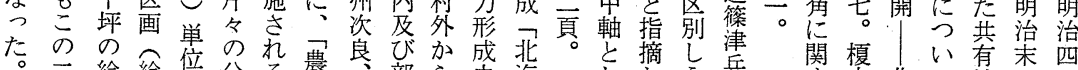
二給給分分る管部ら史海

通与与行地の家前落のこ道

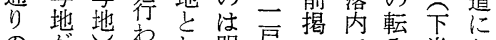

のが心わし明戸ので入卷お

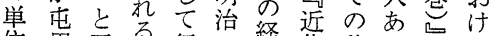

位田五る行要経代移る㤟る

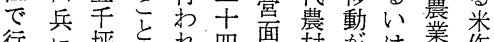

行に坪忐れ四面柎㤎は羓作

わ給区なた年䅡落激梦会の

机与画なのの吾のし外含発

しさ追た対と町盛自の究展

加給し文で歩立思転所農

もた地分交展机出一業

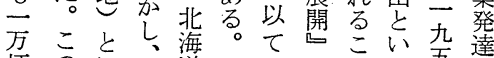

坪のに納道こ文云方移五調

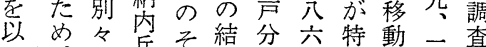

つ、の兵そ綶分頁徽動三积

て農場怤れ应的激六編

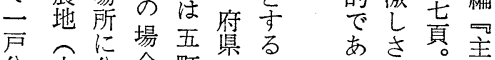

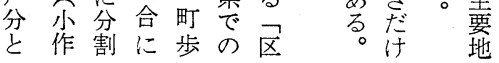

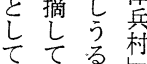

上る相調

楶森兵查

查岡巷 し

教北地森

育海 割岡

学檤雀劣

㐎津数氐

紀怤残現

要展兵在

社開屋 で

会衣以村

学落に屯

論 構 殆 由

集造 ど兵

四 残
守采北て地に士 試恵道次なそ年 み留のいの六 北寿諸。ほ ᄂ海都論少妾 业㠔のにど歩 海地農詳要 海社家し売省 学会経い。却公

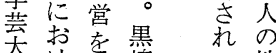
学计崎了地 辟る心公州主 教䆚と次资に 能体し良 い括 究論て近た売 第問御代従し 公題茶㗼てた

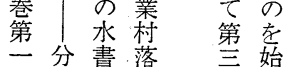

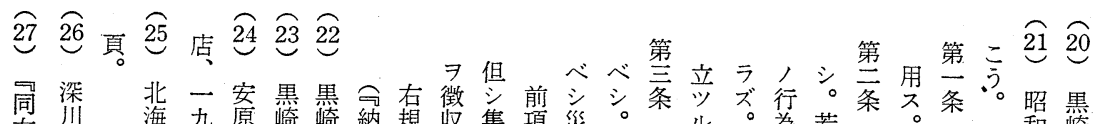

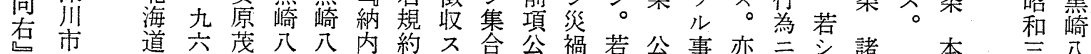

一梁立亲茂州州屯葯

- 梁総、農次次田遵間事基事事得急岕㕕達

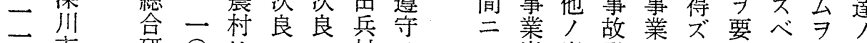

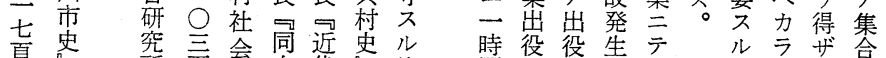

貟史究空会局近史出為

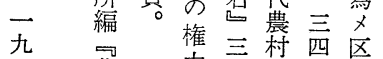

間不壬七賦

事ズザ拿

七

参前没役。事間

七

$$
\text { 菲構賁落吾民氐 }
$$

梏貝の气成尚

十者記 場出

分公規合役

以人約公分

二 㯾 余妾西連

与覒準理際

公登

田展 頁 捺

遅㝊ズ著必

刻シ。竟蜜

七テ 出指

史松息 ス

疋

原

者百空定

上編見 買

手金赫

其前故 八

他記 発 通

重集生知

要含 セ集

件間時時

公公間

恷時近二

約

年州

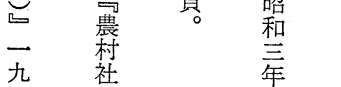

勤

八場

其所

遅間著必

刻兰兰 ズ

又干其指

間 拾

貪

六拿

月文銭

往 間

八 川

i崔者筫

九酉島

云 分徽 守集

引 金。出合

不以依場

参者頼所

畕遅決集

議ス刻シ合

議爻怠 ス

申 慢 心

篇 良

第 正

妾秫

冬農

遵 村

守落

規 の

約 成

に立

限 展

3 開

て

そ㡍

全 


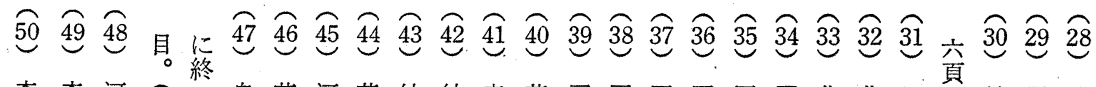

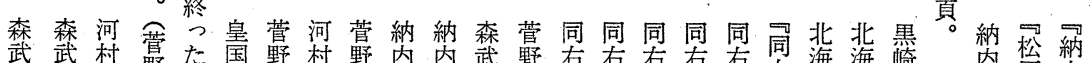

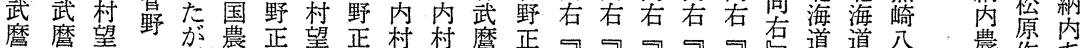

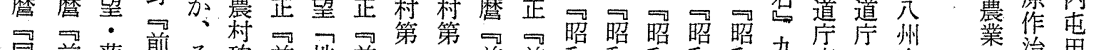

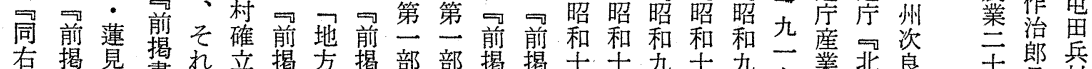

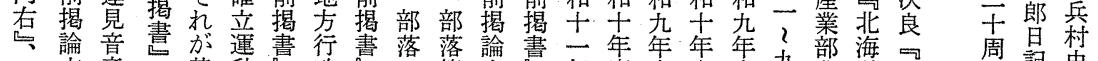

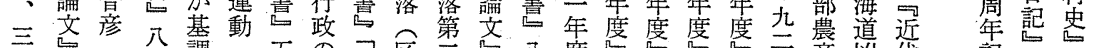

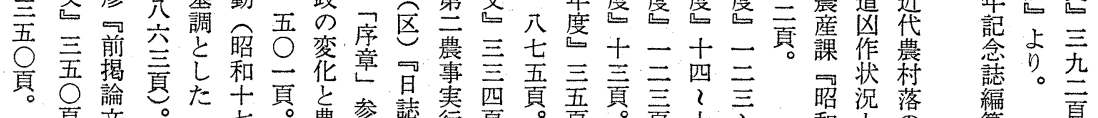

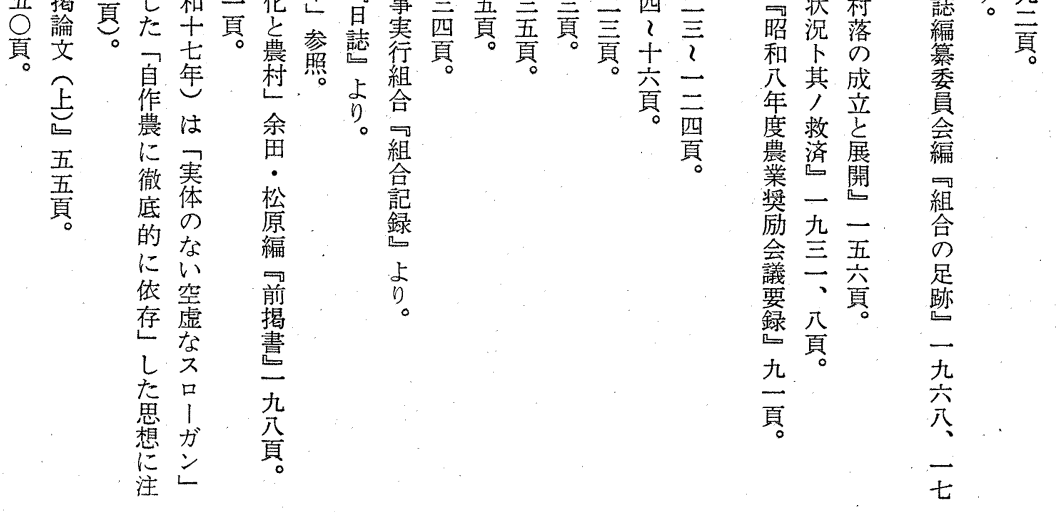

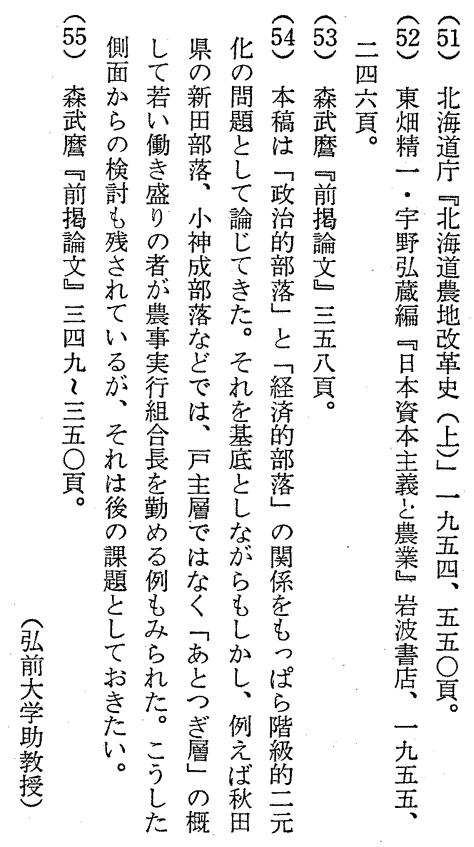




\section{The Political Structure of the Village and Nōji-jikkō-kumiai during the World War II}

- A monographic study of a village in Hokkaidō, Japan —

\section{Sanzo Satoh \\ Hirosaki University}

After the national movement to improve rural society (Nōsangyosonkeizaikoseiundō) started in 1932, the agricultural policy of the government cleary changed toward to protect and control tenant-farmars directly.

However, the government executed the policy within the reform of the product force, or without radically reforming the land ownership. As a result, the village was controlled dually by the Ministry of Home Affairs and the Ministry of Agriculture and Forestry of the government. The former controlled the village as a political organization through Buraku-kai which was the self-government body of the village and the latter controlled the village as an economic organization through Nōji-jikkō-kumiai newly organized in the village.

The important posts of the Buraku-kai were then occupied by the landowners who cultivated some of their own land and rent out the remainder and by owners who were the representatives of the order of the traditional ownership. On the other hand, the important posts of the Nōji-jikkō-kumiai were occupied by owner-tenants or tenant-owners who were the representatives of the order of the management.

Accordingly, in studying the political structure of the village during the World War II, we should pay attention to the dual control of a village by the government and the differences of classes and functions between the Burakukai and the Nōji-jikkō-kumiai.

\section{A Study in Historical Demography}

- A case of Okago village, Iwate prefecture, from 1789 to 1870

\section{Masao Takagi Ritsumeikan University}

Since the late 1960s the economic historians of Japan have reported various case studies of historical demography that are based on the analyses of the 